\title{
PENGARUH CUSTOMER RELATIONSHIP MANAGEMENTDAN KUALITAS PELAYANAN TERHADAP KEPUTUSAN PEMBELIAN PRODUK PT. NUSANTARA SURYA SAKTI SUMBAWA
}

\author{
Dini Asraini \\ Fakultas Ekonomi dan Bisnis, Jurusan Manajemen \\ Universitas Teknologi Sumbawa \\ e-mail: dinnyasraini11@gmail.com
}

\begin{abstract}
Abstrak
Diterima

Penelitian ini bertujuan untuk mengetahui pengaruh customer relationship

Bulan Juli 2019 management dan kualitas pelayanan terhadap keputusan pembelian. Penelitian ini menggunakan jenis penelitian Asosiatif Kuantitatif. Metode pengumpulan data dilakukan dengan membagikan kuesioner pada 100 responden yaitu konsumen PT. Nusantara Surya Sakti Sumbawa. Teknik pengambilan sampel

Diterbitkan

Bulan Juli 2019 menggunakan convenience sampling dan purposive sampling. Analisis data yang digunakan yaitu analisis regresi linear berganda. Berdasarkan hasil penelitian dapat disimpulkan bahwa kedua variabel bebas yaitu customer

Keyword:

Customer

Relationship relationship management dan kualitas pelayanan mempunyai pengaruh positif dan signifikan terhadap keputusan pembelian.
\end{abstract}

Management,

Kualitas

Pelayanan dan

Keputusan

Pembelian

\section{PENDAHULUAN}

\section{Latar Belakang}

Pada era perkembangan bisnis belakang ini, akan terus berjalan dan berubah seiring dengan perkembangan zaman. Dengan perubahan tersebut maka tidak ada lagi lingkungan bisnis yang statis, sehingga kebijakan-kebijakan bisnis tidak dapat dipertahankan. Lingkungan internal bisnis harus terus menerus diupayakan untuk menyesuaikan perubahan tersebut melalui penetapan strategi bisnis perusahaan. Penyesuaian yang dibutuhkan berkaitan dengan peningkatan kapabilitas dan kompetensi sumber daya organisasi perusahaan. Salah satu faktor atau dimensi yang cepat berubah adalah pelanggan, baik pelanggan konsumen akhir maupun pelanggan organisasi atau pelanggan bisnis. Dengan terdapatnya perubahan tersebut, maka setiap perusahaan haruslah melakukan perencanaan bagi penyesuaian hubungan bisnis antara pemasar perubahan dengan para pelanggan harus dapat dibina untuk jangka panjang secara berkelanjutan. "Upaya pembinaan hubungan relational dimaksudkan agar dapat ditingkatkannya nilai pelanggan secara berkesinambungan" (Assauri, 2012:145).

Perusahaan dalam memenuhi hal tersebut, harus mampu menyediakan produk yang mutunya lebih baik, harganya yang lebih murah, informasi lebih cepat dan pelayanan yang lebih baik dibanding pesaingnya. Semakin berkembangnya $E$ business, memaksa perusahaan menggunakan solusi dan aplikasi yang tepat untuk dapat mempertahankan bisnisnya. Perusahaan tidak lagi memikirkan keuntungan semata tetapi mulai memerhatikan sektor potensial lainnya yang dapat mempertahankan atau meningkatkan pendapatan sehingga kepentingan pelanggan pun menjadi perhatian utama. Karenanya berbagai upaya dilakukan agar hubungan pelanggan dengan perusahaan berjalan dengan baik (Wirawan, 2008).

PT. Nusantara Surya Sakti atau yang biasa disebut NSS merupakan salah satu perusahaan yang bergerak di bidang otomotif atau dealer kendaraan bermotor roda dua dengan merek Honda. Perusahaan dengan komitmen besar untuk menjadi dealer terbesar di Indonesia ini telah memiliki 87 dealer yang telah tersebar di seluruh wilayah Indonesia. Selain itu, PT. Nusantara Surya Sakti bergerak dalam usaha di bidang pengiriman barang dan kargo dengan nama NSS Express yang sampai saat ini memiliki 123 cabang yang tersebar di seluruh provinsi dan Kabupaten di seluruh indonesia. Salah satu cabang di Kabupaten Sumbawa yang letaknya di JL. Dr. Sutomo, RT 01 RW 05 Brang Bara Kecamatan Sumbawa. Dengan bertambahnya saingan dan semakin kompetitifnya pasar otomotif, NSS berusaha meningkatkan 
penjualan serta mutu pelayanan terhadap konsumen. Oleh karena itu, perlu adanya usaha lain yang lebih spesifik yang harus dilaksanakan oleh pihak perusahaan agar dapat memenuhi segala kebutuhan dan keinginan konsumennya dibandingkan dengan apa yang diberikan oleh pesaingnya (www.nssexpress.co.id).

\section{Customer Relationship Management} (CRM) merupakan salah satu pendekatan bisnis yang berbasis pengelolaan hubungan atau relasi dengan pelanggan. CRM lebih memfokuskan pada apa yang dinilai pelanggan bukan kepada produk yang ingin dijual oleh perusahaan. Hal ini perlu diperhatikan karena dapat memengaruhi keputusan pembelian konsumen karena melalui penerapan CRM, perusahaan diharapkan dapat membangun komunikasi dan hubungan yang baik dengan para konsumennya sehingga dalam menghasilkan suatu produk perusahaan tidak hanya menjual dan memasarkan suatu produk dengan kualitas yang baik atau harga yang bersaing tetapi juga dapat menjawab keinginan dan kebutuhan konsumen (Imasari dan Nursalin, 2011).

Kualitas pelayanan saat ini juga sangat diperlukan oleh suatu perusahaan, dimana hal ini berkaitan erat dengan kepuasan pelanggan. Kualitas layanan memberikan dorongan khusus bagi para pelanggan untuk menjalin ikatan relasi saling menguntungkan dalam jangka panjang perusahaan. Ikatan emosional semacam ini memungkinkan perusahaan untuk memahami secara seksama harapan dan kebutuhan spesifik pelanggan (Kalalo, 2013). Layanan berkualitas dibutuhkan dalam perusahaan untuk memenangkan pasar dalam dunia persaingan. Dimana keberhasilan suatu perusahaan dalam memberikan kualitas yang baik dapat memengaruhi dan menumbuhkan kepercayaan konsumen terhadap keputusan pembelian. Keinginan konsumen akan sepeda motor memberikan sikap tersendiri karena konsumen selalu menginginkan produk yang terbaik dan inovasi yang sesuai dengan selera konsumen (Siow, 2013).

\section{Rumusan Masalah}

1. Bagaimana customer relationship management berpengaruh terhadap keputusan pembelian produk PT. Nusantara Surya Sakti ?

2. Bagaimana kualitas pelayanan berpengaruh terhadap keputusan pembelian produk PT. Nusantara Surya Sakti ?

3. Bagaimana customer relationship management dan kualitas pelayanan berpengaruh secara simultan terhadap keputusan pembelian produk PT. Nusantara Surya Sakti ?

\section{Hipotesis Penelitian}

Hipotesis adalah pernyataan sementara yang masih lemah kebenarannya, maka perlu diuji kebenarannya (Siregar, 2013:38).
- $\mathrm{H}_{1}$ : Customer Relationship Management berpengaruh terhadap Keputusan Pembelian

- $\mathrm{H}_{2}$ : Kualitas Pelayanan berpengaruh terhadap Keputusan Pembelian

- $\mathrm{H}_{3}$ : Customer Relationship Management dan kualitas pelayanan berpengaruh secara simultan terhadap keputusan pembelian

\section{STUDY PUSTAKA}

\section{Customer Relationship Management}

Customer Relationship Management (CRM) menjadi istilah yang populer dalam beberapa tahun terakhir. Ditambah dengan perkembangan teknologi informasi yang semakin merambah berbagai aplikasi bisnis, CRM menjadi salah satu proses bisnis yang menarik untuk diperbincangkan. Menurut Kotler dan Keller (2009:148) Customer relationship management merupakan proses mengelola informasi tentang masing-masing pelanggan dan secara cermat mengelola semua "titik sentuh" pelanggan demi memaksimalkan kesetiaan pelanggan.

Menurut Gordon (2002:2) untuk memudahkan penilaian dan untuk mengukur keputusan pembelian atas Customer Relationship Management meliputi empat dimensi, yaitu:

a. Teknologi: teknologi yang mendukung CRM.

b. Proses: proses yang digunakan perusahaan untuk mengakses dan berinteraksi dengan pelanggan mereka dalam mengejar nilai baru dan kepuasan timbal balik.

c. Pengetahuan dan Pemahaman: pendekatan yang digunakan perusahaan untuk menambah nilai pada data pelanggan, sehingga mereka memperoleh pengetahuan dan wawasan yang diperlukan untuk memperdalam suatu hubungan.

d. Orang (Sumber Daya Manusia): Keterampilan, kemampuan dan sikap orang-orang yang mengelola CRM.

\section{Kualitas Pelayanan}

Lupiyoadi (2001:148) Kualitas pelayanan adalah seberapa jauh perbedaan antara harapan dan kenyataan para pelanggan atas layanan yang diterima. Untuk memudahkan penilaian dan untuk mengukur keputusan pembelian atas kualitas pelayanan yang meliputi lima dimensi, yaitu:

a. Tangibles (bukti langsung), yaitu kemampuan suatu perusahaan dalam menunjukkan eksistensinya kepada pihak eksternal. Penampilan dan kemampuan sarana dan prasarana fisik perusahaan dan keadaan lingkungan sekitarnya adalah bukti nyata dari pelayanan yang diberikan perusahaan.

b. Reliability (kehandalan), yaitu kemampuan untuk memberikan pelayanan yang dijanjikan dengan segera, akurat, dan memuaskan. Kinerja harus sesuai dengan harapan 
konsumen yang berarti ketepatan waktu, pelayanan yang sama untuk semua konsumen tanpa kesalahan, sikap simpatik, dan akurasi yang tinggi.

c. Responsiveness (daya tanggap), yaitu kemampuan untuk membantu memberikan pelayanan yang cepat (responsif) dan tepat kepada konsumen dengan penyampaian informasi yang jelas. Membiarkan konsumen menunggu tanpa adanya alasan yang jelas menyebabkan persepsi yang negatif dalam kualitas pelayanan.

d. Assurance (jaminan), adanya kepastian yaitu pengetahuan, kesopan santunan dan kemampuan para pegawai perusahaan untuk menumbuhkan rasa percaya para konsumen kepada pelayanan perusahaan.

e. Emphaty (empati) atau Knowing the customer, yaitu memberikan perhatian yang tulus dan bersifat individu atas pribadi yang diberikan kepada para konsumen dengan berupaya memahami keinginan konsumen. Suatu perusahaan diharapkan memiliki pengertian dan pengetahuan tentang konsumen, memahami kebutuhan konsumen secara spesifik, serta memiliki waktu pengoperasian yang nyaman bagi konsumen.

\section{Keputusan Pembelian}

Sangadji dan Sopiah (2013:37) Keputusan pembelian merupakan suatu tahap dalam proses pengambilan keputusan pembelian sampai konsumen benar-benar membeli produk. Menurut Hasan, (2014:181), pengambilan keputusan pembelian berlangsung secara berurutan dalam lima tahapan (indikator) yaitu:

1. Pengenalan Masalah

Masalah timbul dari dalam diri konsumen yang berupa kebutuhan, yang digerakkan oleh rangsangan dari dalam diri pembeli atau dari luar.

2. Mencari Informasi

Konsumen akan mencari informasi tentang objek yang dapat memuaskan keinginannya. Pencarian informasi masih tergantung oleh kuat lemahnya kebutuhan akan kebutuhan yang dimiliki kemudian mengandalkan penilaian terhadap informasi yang diperolehnya.

3. Evaluasi Alternatif

Dari informasi yang diperoleh konsumen, digunakan untuk memperoleh gambaran yang lebih jelas mengenai alternatif-alternatif yang dihadapi serta alternatif masing-masing. Untuk mengetahui proses evaluasi yang dilakukan konsumen terlebih dahulu harus dipahami atribut golongan produk, keyakinan merek dagang, pembeli kemungkinan besar beranggapan bahwa kepuasan dapat diperoleh dari tiap produk berubah-ubah dengan berubahnya tingkat alternatif dari tiap atribut dan konsumen menentukan sikap terhadap merek melalui proses evaluasi.

4. Keputusan Pembelian

Tahap evaluasi berakibat bahwa konsumen membentuk preferensi diantara alternatif-alternatif merek barang. Biasanya barang dengan merek yang disukai adalah barang yang akan dibelinya. Disamping sikap, masih ada dua faktor yang memengaruhi nilai seseorang untuk membeli yaitu: faktor sosial dan faktor situasi

5. Evaluasi Purnabeli

Setelah melakukan pembelian konsumen akan merasakan kepuasan atau mungkin ketidakpuasan. Produsen harus memerhatikan tindakan konsumen setelah melakukan pembelian. Konsumen dalam hal memenuhi keinginannya, mempunyai pengharapan agar bisa terpuaskan. Pengharapan konsumen timbul dari pesan-pesan yang diterima oleh penjual, teman dan sumber lain bahkan dari perusahaan sendiri.

\section{Kerangka Konseptual}

Berdasarkan landasan teori dan penelitian terdahulu maka dapat disusun suatu kerangka konseptual dalam penelitian ini seperti berikut:

Gambar 2.1

Kerangka Konseptual

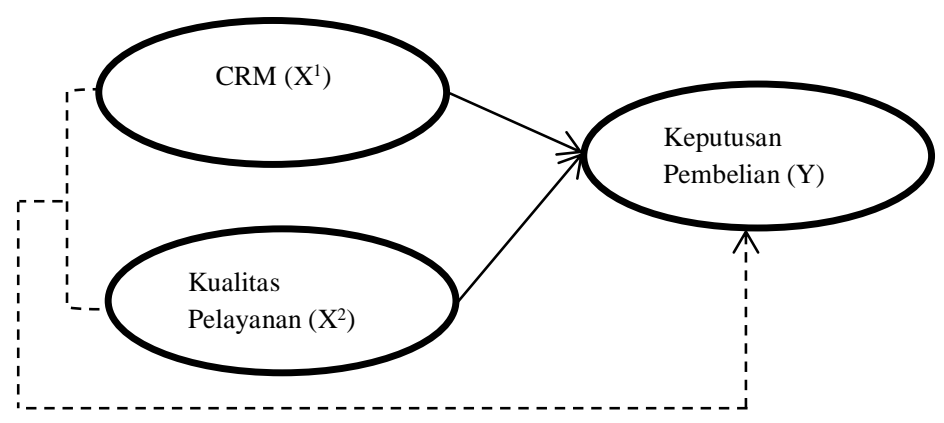

Keterangan:

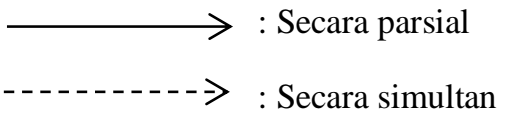

Kerangka konseptual menggambarkan hubungan variabel independen, dalam hal ini adalah customer relationship managemen $\left(\mathrm{X}_{1}\right)$, kualitas pelayanan $\left(\mathrm{X}_{2}\right)$ dan variabel dependen adalah keputusan pembelian (Y). 


\section{METODE PENELITIAN}

\section{Rancangan Penelitian}

Jenis Penelitian yang digunakan oleh peneliti yaitu penelitian asosiatif dengan menggunakan metode kuantitatif. Menurut Sugiyono, (2015:11), penelitian berdasarkan tingkat eksplanasinya (tingkat kejelasan) jenis penelitian asosiatif dengan metode kuantitatif. Penelitian asosiatif merupakan penelitian yang bertujuan untuk mengetahui pengaruh ataupun juga hubungan antara dua variabel atau lebih. Penelitian ini mempunyai tingkatan tertinggi dibandingkan dengan deskriptif dan komparatif, karena dengan penelitian ini dapat dibangun suatu teori yang dapat berfungsi untuk menjelaskan, meramalkan dan mengontrol suatu gejala. Menurut Sugiyono, (2015:14), penelitian kuantitatif adalah penelitian dengan memperoleh data yang berbentuk angka atau data kualitatif yang diangketkan.

\section{Populasi dan Sampel}

Populasi adalah seluruh komponen elemen yang menunjukkan ciri-ciri tertentu yang dapat digunakan untuk membuat kesimpulan. Jadi, kumpulan elemen itu menunjukkan jumlah, sedangkan ciri-ciri tertentu menunjukkan karakteristik dari kumpulan itu (Sanusi, 2011:87). Populasi dalam penelitian ini adalah seluruh konsumen PT. Nusantara Surya Sakti.

Sampel merupakan bagian dari populasi (Lerbin, 2007:95). Pada penelitian ini populasi yang diambil berukuran besar dan jumlahnya tidak diketahui secara pasti. Jadi, Penentuan jumlah sampel ditentukan dengan menggunakan rumus sebagai berikut (Widiyanto, 2008:59):

$n=\frac{z^{2}}{4(M o e)^{2}}$

Keterangan:

$\mathrm{n}=$ Jumlah Sampel

$\mathrm{Z}=$ Score pada tingkat signifikan tertentu $(95 \%)$

Moe $=$ Margin of eror yaitu tingkat kesalahan maksimal pengambilan sampel yang masih dapat ditoleransi atau yang diinginkan sebesar (5\%).

$n=\frac{(1,96)^{2}}{4(5 \%)^{2}}=\frac{3,8416}{4(0,005)^{2}}$

$n=\frac{3,8416}{0,04}=96,04$ dibulatkan 100

Dari hasil perhitungan rumus diatas dapat diperoleh jumlah sampel yang akan diteliti adalah sebesar 100 responden. Jumlah sampel yang ditentukan adalah 100 orang konsumen yang membeli produk PT. Nusantara Surya Sakti Sumbawa. Tehnik pengambilan sampel yang digunakan oleh peneliti adalah Non Probability Sampling yaitu teknik pengambilan sampel yang tidak memberikan peluang atau kesempatan yang sama bagi setiap unsur atau anggota populasi untuk dipilih menjadi anggota sampel. Dengan menggunakan metode Convenience Sampling dan Purposive Sampling dimana Convenience Sampling adalah teknik penentuan sampel berdasarkan kebetulan saja, anggota populasi yang ditemui peneliti dan bersedia menjadi responden untuk dijadikan sampel atau peneliti memilih orang-orang terdekat saja. Sedangkan, Purposive Sampling merupakan metode penetapan responden yang berdasarkan pada pertimbangan tertentu (Siregar, 2013:33). Pertimbangan yang digunakan dalam penelitian ini adalah konsumen minimal 17 tahun ke atas, yang telah membeli dan merasakan pelayanan di PT. Nusantara Surya Sakti Sumbawa.

\section{Pengumpulan Data}

Data yang diperoleh langsung dari sumber atau subjek penelitian. Sumber data primer adalah data yang diperoleh secara langsung dengan membagi kuisioner kepada responden. Data yang diperoleh secara tidak langsung melalui media cetak seperti buku, jurnal, katalog perusahaan, dan keterangan lain yang berhubungan dengan pokok penelitian. Dalam hal ini, sumber data sekunder adalah dokumentasi.

\section{Analisis Data}

\section{Uji Validitas dan Uji Reliabilitas}

\section{Uji Validitas}

Menurut Siregar (2013:46), uji validitas adalah bukti bahwa instrumen, teknik atau proses yang digunakan untuk mengukur sebuah konsep benar-benar mengukur konsep yang dimaksudkan. Uji validitas bertujuan untuk mengukur valid tidaknya suatu item pertanyaan. Validitas menunjukkan sejauh mana alat ukur mampu mengukur apa yang ingin diukur.

Uji validitas dilakukan dengan membanding nilai $r_{\text {hitung }}$ dengan $r_{\text {tabel. }}$ Kriteria uji validitas:

- $\quad$ Apabila $r_{\text {hitung }}>r_{\text {tabel, }}$ maka item kuesioner tersebut valid.

- Apabila $r_{\text {hitung }}<r_{\text {tabel, }}$ maka item kuesioner tersebut tidak valid.

Tabel 3.2

Hasil Uji Validitas

\begin{tabular}{|l|c|c|c|c|}
\hline Variabel & $\begin{array}{c}\text { Item } \\
\text { Pertany } \\
\text { aan }\end{array}$ & $\mathrm{r}_{\text {hitung }}$ & $\mathrm{r}_{\text {tabel }}$ & $\begin{array}{c}\text { Keter } \\
\text { angan }\end{array}$ \\
\hline $\begin{array}{l}\text { Customer } \\
\text { Relationship } \\
\text { Management } \\
\text { (X) }\end{array}$ & CRM1 & 0,616 & 0,361 & Valid \\
\cline { 2 - 5 } & CRM2 & 0,616 & 0,361 & Valid \\
\cline { 2 - 5 } & CRM3 & 0,445 & 0,361 & Valid \\
\cline { 2 - 5 } & CRM4 & 0,594 & 0,361 & Valid \\
\cline { 2 - 5 } & CRM5 & 0,456 & 0,361 & Valid \\
\hline
\end{tabular}




\begin{tabular}{|l|c|c|c|c|}
\hline & CRM6 & 0,669 & 0,361 & Valid \\
\hline Kualitas & KL1 & 0,701 & 0,361 & Valid \\
\cline { 2 - 5 }$\left(\right.$ X $\left._{2}\right)$ & KL2 & 0,717 & 0,361 & Valid \\
\cline { 2 - 5 } & KL3 & 0,600 & 0,361 & Valid \\
\cline { 2 - 5 } & KL4 & 0,509 & 0,361 & Valid \\
\cline { 2 - 5 } & KL5 & 0,650 & 0,361 & Valid \\
\cline { 2 - 5 } & KL6 & 0,571 & 0,361 & Valid \\
\cline { 2 - 5 } & KL7 & 0,488 & 0,361 & Valid \\
\cline { 2 - 5 } & KL8 & 0,416 & 0,361 & Valid \\
\cline { 2 - 5 } & KL9 & 0,376 & 0,361 & Valid \\
\hline \multirow{4}{*}{$\begin{array}{l}\text { Keputusan } \\
\text { Pembelian }\end{array}$} & KP1 & 0,674 & 0,361 & Valid \\
\cline { 2 - 5 } & KP2 & 0,576 & 0,361 & Valid \\
\cline { 2 - 5 } & KP3 & 0,671 & 0,361 & Valid \\
\cline { 2 - 5 } & KP4 & 0,460 & 0,361 & Valid \\
\cline { 2 - 5 } & KP5 & 0,459 & 0,361 & Valid \\
\cline { 2 - 5 } & KP6 & 0,503 & 0,361 & Valid \\
\cline { 2 - 5 } & KP7 & 0,674 & 0,361 & Valid \\
\hline
\end{tabular}

Sumber: hasil pengelolaan data SPSS 16.0

\section{Uji Reliabilitas}

Menurut Siregar (2013:46), uji reliabilitas adalah untuk mengetahui sejauh mana hasil pengukuran tetap konsisten, apabila dilakukan pengukuran dua kali atau lebih terhadap gejala yang sama dengan menggunakan alat pengukur yang sama pula. Uji reliabilitas merupakan suatu alat yang digunakan untuk mengukur suatu koesioner yang merupakan indikator dari variabel.

Adapun cara yang digunakan untuk menguji reliabilitas kuesioner dalam penelitian ini adalah menggunakan nilai koefisien Alpha Cronbach, yaitu:

- Apabila hasil koefisien Alpha > taraf signifikansi 60\% atau 0,6 maka kuesioner tersebut reliabel

- Apabila hasil koefisien Alpha < taraf signifikansi 60\% atau 0,6 maka kuesioner tersebut tidak reliabel

Tabel 3.3

Hasil Uji Reliabilitas

\begin{tabular}{|l|c|c|c|}
\hline \multicolumn{1}{|c|}{ Variabel } & $\begin{array}{l}\text { Koefisien } \\
\text { alpha }\end{array}$ & $\begin{array}{l}\text { Taraf } \\
\text { signifikansi }\end{array}$ & Keterangan \\
\hline $\begin{array}{l}\text { Customer } \\
\text { Relationship } \\
\text { Management }\end{array}$ & 0,725 & 0,60 & Reliabel \\
\hline $\begin{array}{l}\text { Kualitas } \\
\text { Pelayanan }\end{array}$ & 0,731 & 0,60 & Reliabel \\
\hline $\begin{array}{l}\text { Keputusan } \\
\text { Pembelian }\end{array}$ & 0,733 & 0,60 & Reliabel \\
\hline
\end{tabular}

Sumber: hasil pengelolaan data SPSS 16.0

\section{Uji Asumsi Klasik}

Menurut Sunyoto (2011:131) model regresi linier berganda dapat disebut baik jika terbatas dari asumsi-asumsi klasik statistik. Penelitian ini akan dilakukan beberapa uji asumsi klasik yang meliputi uji normalitas, uji linearitas, uji multikolinearitas dan uji heteroskedastisitas.

1. Uji Normalitas

Uji normalitas bertujuan untuk menguji apakah dalam model regresi variabel terikat, variabel bebas atau keduanya mempunyai distribusi normal atau tidak. Pengujian normalitas dalam penelitian ini menggunakan bantuan program SPSS Statistic 16 Windows dengan statistik One Sample Kolmogrov Smirnov Test. Pengukuran yang digunakan adalah membandingkan nilai asymp. Sig (2tailed) dengan nilai yang ditentukan sebesar 5\%. Apabila nilai asymp. Sig (2-tailed) lebih besar dari 0,05 maka dapat disimpulkan bahwa data tersebut berdistribusi normal. Hasil uji normalitas adalah sebagai berikut:

Tabel 4.4 Hasil Uji Normalitas One-Sample Kolmogorov-Smirnov Test

\begin{tabular}{|ll|r|}
\hline & & \multicolumn{2}{|c|}{$\begin{array}{c}\text { Unstandardized } \\
\text { Residual }\end{array}$} \\
\hline $\mathrm{N}$ & Mean & 100 \\
Normal & .0000000 \\
Parameters & \\
& Std. & 2.00575818 \\
Most Extreme & Deviation & Absolute \\
Differences & Positive & .048 \\
& Negative & .041 \\
Kolmogorov-Smirnov Z &. .048 \\
Asymp. Sig. (2-tailed) & .477 \\
\hline
\end{tabular}

Sumber: hasil pengelolaan data SPSS 16.0

Berdasarkan Tabel 4.4 hasil uji normalitas di atas diperoleh Asymp. Sig (2tailed) sebesar 0,977 yang berarti lebih besar dari 0,05, maka dapat disimpulkan bahwa data dalam penelitian ini mempunyai distribusi normal.

2. Uji Linearitas

Uji linearitas bertujuan untuk mengetahui apakah dua variabel mempunyai hubungan yang linear atau tidak secara signifikan, uji ini biasanya digunakan sebagai sebagai prasyarat dalam analisis korelasi atau regresi linear. Pengujian pada SPSS menggunakan test for lineary pada taraf signifikan 0,05. Dua variabel dikatakan mempunyai hubungan yang linear bila signifikansi (lineary) kurang dari 0,05. Hasil uji dapat dilihat pada tabel berikut: 
Keputusan Pembelian dan CRM

ANOVA Table

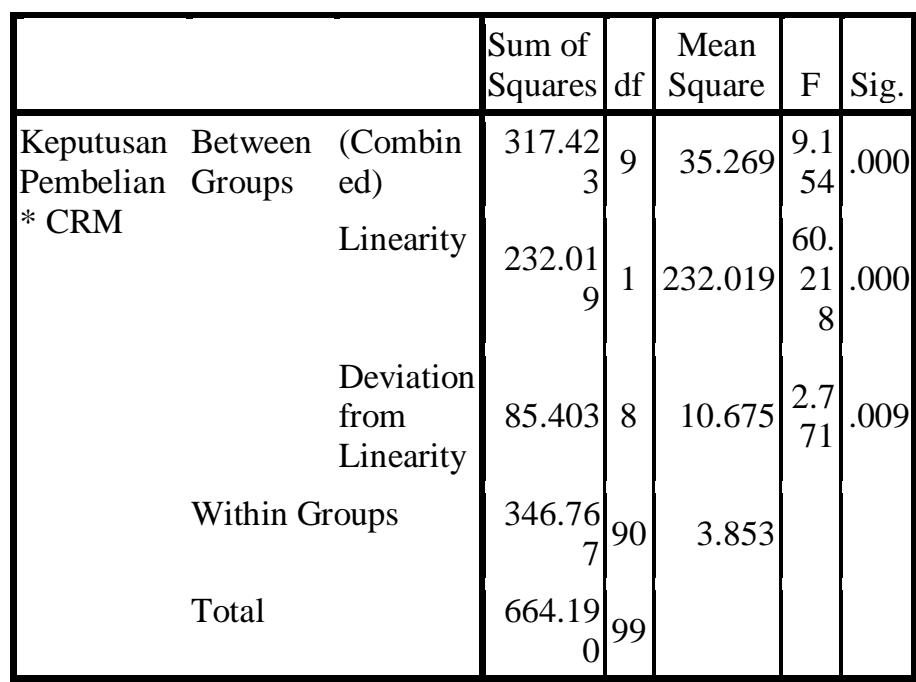

Sumber: hasil pengelolaan data SPSS 16.0

Berdasarkan tabel di atas diketahui nilai signifikan Linearity antara CRM dan keputusan pembelian yaitu 0,000 < 0,05 yang artinya bahwa secara statistik CRM berpengaruh secara linear terhadap keputusan pembelian.

Tabel 4.6 Hasil Uji Linearitas Keputusan Pembelian dan Kualitas Pelayanan ANOVA Table

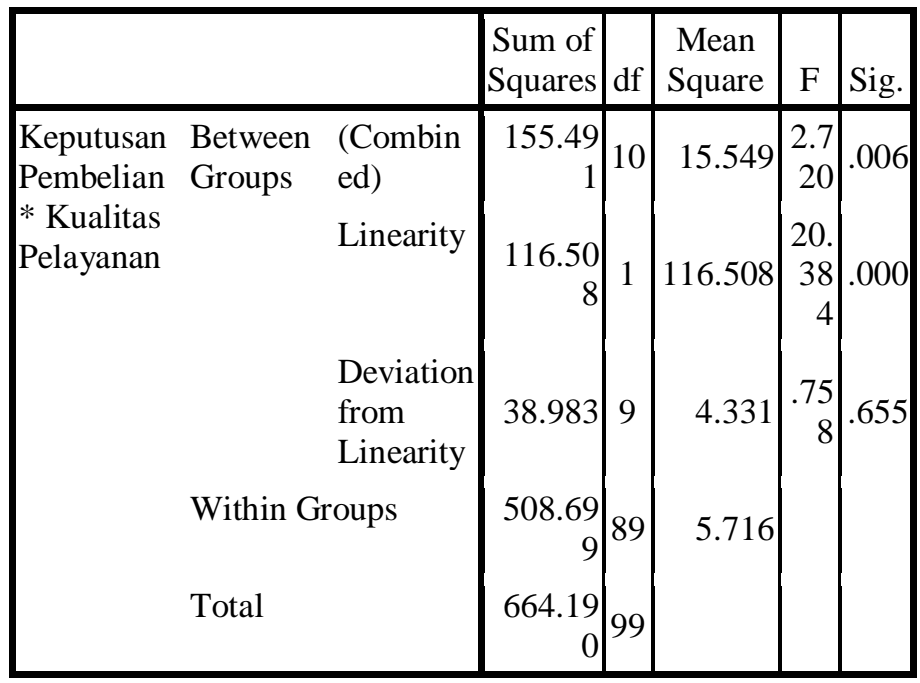

Sumber: hasil pengelolaan data SPSS 16.0

Berdasarkan tabel di atas diketahui nilai signifikan Linearity antara kualitas pelayanan dan keputusan pembelian yaitu $0,000<0,05$ yang artinya bahwa secara statistik kualitas pelayanan berpengaruh secara linear terhadap keputusan pembelian.

3. Uji Multikolinearitas
Uji multikolinearitas bertujuan untuk mengetahui apakah terdapat gejala korelasi antar variabel independen lainnya. Model regresi yang baik seharusnya tidak terjadi korelasi di antara variabel bebas. Pemeriksaan untuk mendeteksi gejala multikolinieritas dilakukan dengan melihat nilai tolerance dan VIF (Variance Inflation Factor) yang dihitung dengan menggunakan SPSS Statisic 16 for window. Hasil uji multikolinieritas disajikan dalam tabel berikut:

Tabel 4.7 Hasil Uji

Multikolinearitas

\begin{tabular}{lccl}
\hline Variabel & $\begin{array}{l}\text { Toleranc } \\
\text { e }\end{array}$ & VIF & Keterangan \\
\hline CRM & 0,877 & 1,140 & $\begin{array}{l}\text { Tidak terjadi } \\
\text { multikolinea } \\
\text { ritas }\end{array}$ \\
$\begin{array}{l}\text { Kualitas } \\
\text { Pelayana } \\
\text { n }\end{array}$ & 0,877 & 1,140 & $\begin{array}{l}\text { Tidak terjadi } \\
\text { multikolinea } \\
\text { ritas }\end{array}$ \\
\hline Sumber: hasil pengelolaan data SPSS 16.0
\end{tabular}

Tabel 4.7 di atas menunjukkan bahwa variabel $\mathrm{CRM}\left(\mathrm{X}_{1}\right)$ dengan nilai tolerance $0,877>0,1$ dan nilai VIF $1,140<10$ dan Kualitas Pelayanan $\left(\mathrm{X}_{2}\right)$ dengan nilai tolerance $0,877>0,1$ dan nilai VIF $1,140<$ 10. Maka dapat disimpulkan bahwa semua variabel bebas tidak terjadi multikolinearitas.

4. Uji Heteroskedastisitas

Heteroskedastisitas yakni menunjukan bahwa adanya varian variabel tidak sama untuk semua observasi. Untuk mendeteksi ada atau tidaknya heteroskedastisitas dalam penelitian ini menggunakan pengujian Glejser dengan syarat jika nilai Sig. diatas 0.05 maka tidak terjadi heteroskedastisitas. Dalam pengujian heteroskedastisitas menggunakan bantuan SPSS statistic for windows 16. Hasil uji heteroskedastisitas dapat dilihat pada tabel berikut:

Tabel 4.8 Hasil Uji

Heteroskedastisitas

Coefficients $^{\mathrm{a}}$

\begin{tabular}{|c|c|c|c|c|c|}
\hline \multirow[b]{2}{*}{ Model } & \multicolumn{2}{|c|}{$\begin{array}{l}\text { Unstandard } \\
\text { ized } \\
\text { Coefficient } \\
\text { s }\end{array}$} & \multirow{2}{*}{$\begin{array}{c}\text { Standardized } \\
\text { Coefficients } \\
\text { Beta }\end{array}$} & \multirow[b]{2}{*}{$\mathrm{t}$} & \multirow[b]{2}{*}{ Sig. } \\
\hline & B & $\begin{array}{l}\text { Std. } \\
\text { Error }\end{array}$ & & & \\
\hline 1 (Constant) & $\begin{array}{r}2.58 \\
2\end{array}$ & 1.768 & & 1.460 & .148 \\
\hline CRM & $\begin{array}{r}- \\
.045\end{array}$ & .079 & -.062 & -.576 & .566 \\
\hline
\end{tabular}




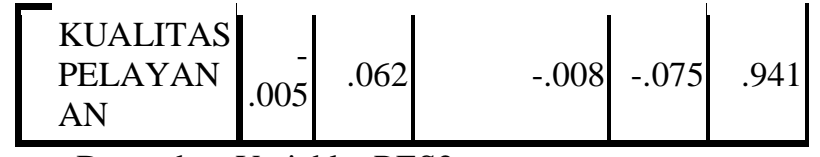

a. Dependent Variable: RES2

Sumber: hasil pengelolaan data SPSS 16.0

Dari Tabel 4.8 menunjukkan bahwa nilai signifikansi dari CRM $\left(\mathrm{X}_{1}\right)$ sebesar 0,566 > 0,05 dan nilai sig. dari kualitas pelayanan $\left(\mathrm{X}_{2}\right)$ sebesar 0,941 > 0,05 maka dapat disimpulkan bahwa kedua variabel bebas dalam penelitian ini tidak terindikasi heteroskedastisitas atau terjadinya homokedastisitas

\section{Analisis Regresi Linear Berganda}

Analisis regresi linear berganda digunakan untuk mengetahui pengaruh customer relationship management $\left(\mathrm{X}_{1}\right)$ dan kualitas pelayanan $\left(\mathrm{X}_{2}\right)$ terhadap keputusan pembelian (Y). Adapun persamaan yang digunakan dalam penelitian ini adalah sebagai berikut:

$$
Y=\alpha+b_{1} x_{1}+b_{2} x_{2}+e
$$

\section{Tabel 4.9 Hasil Analisis Regresi Linear Berganda}

\section{Coefficients $^{\mathrm{a}}$}

\begin{tabular}{|c|c|c|c|c|c|}
\hline \multirow[b]{2}{*}{ Model } & \multicolumn{2}{|c|}{$\begin{array}{c}\text { Unstandardized } \\
\text { Coefficients }\end{array}$} & \multirow{2}{*}{$\begin{array}{c}\text { Standardized } \\
\text { Coefficients } \\
\text { Beta }\end{array}$} & \multirow[b]{2}{*}{$\mathrm{T}$} & \multirow[b]{2}{*}{ Sig. } \\
\hline & B & $\begin{array}{l}\text { Std. } \\
\text { Error }\end{array}$ & & & \\
\hline 1 (Constant) & .408 & 3.004 & & .136 & .892 \\
\hline CRM & .809 & .134 & .506 & 6.032 & .000 \\
\hline $\begin{array}{l}\text { Kualitas } \\
\text { Pelayanan }\end{array}$ & .302 & .105 & .241 & 2.873 & .005 \\
\hline
\end{tabular}

a. Dependent Variable: Keputusan Pembelian

Sumber: hasil pengelolaan data SPSS 16.0

Berdasarkan hasil analisis regresi pada Tabel 4.9 maka dapat diketahui persamaan regresi sebagai berikut:

$$
\mathrm{Y}=0,408+0,809 \mathrm{X}_{1}+0,302 \mathrm{X}_{2}+\mathrm{e}
$$

Hasil persamaan regresi berganda di atas dapat memberikan pengertian sebagai berikut:

a. Nilai konstanta sebesar 0,408 menunjukkan bahwa ketika nilai variabel independen yaitu variabel CRM dan kualitas pelayanan diasumsikan diabaikan, maka nilai keputusan pembelian sebesar 0,408 . b. Nilai koefisien regresi variabel CRM bernilai positif yaitu 0,809 menunjukkan apabila nilai CRM mengalami kenaikan satu satuan sementara variabel independen lainnya diasumsikan tetap, maka nilai keputusan pembelian akan meningkat sebesar 0,809 satuan.

c. Nilai koefisien regresi variabel kualitas pelayanan bernilai positif yaitu 0,302 menunjukkan apabila nilai kualitas pelayanan mengalami kenaikan satu satuan sementara variabel independen lainnya diasumsikan tetap, maka nilai keputusan pembelian akan meningkat sebesar 0,302 satuan.

\section{Uji Hipotesis}

1. Uji Parsial (Uji t)

Uji t digunakan untuk menguji apakah pernyataan dalam hipotesis itu benar. Uji-t pada dasarnya menunjukkan seberapa jauh pengaruh suatu variabel independen secara individual dalam menerangkan variabel dependen, pengujian menggunakan tingkat signifikansi 0,05. Jika nilai sig. > 0,05 maka Ho diterima dan $\mathrm{Ha}$ ditolak sedangkan jika nilai sig. < 0,05 maka Ho ditolak dan Ha diterima. Dari uji t dengan bantuan software SPSS for window Versi 16 didapatkan hasil sebagai berikut:

Tabel 4.10 Hasil Uji Parsial (Uji t)

\begin{tabular}{|c|c|c|c|c|c|}
\hline \multirow[b]{2}{*}{ Model } & \multicolumn{2}{|c|}{$\begin{array}{l}\text { Unstandardize } \\
\text { d Coefficients }\end{array}$} & \multirow{2}{*}{\begin{tabular}{|c|}
$\begin{array}{c}\text { Standardized } \\
\text { Coefficients }\end{array}$ \\
Beta \\
\end{tabular}} & \multirow[b]{2}{*}{$\mathrm{T}$} & \multirow[b]{2}{*}{ Sig. } \\
\hline & B & $\begin{array}{l}\text { Std. } \\
\text { Error }\end{array}$ & & & \\
\hline 1 (Constant) & .408 & 3.004 & & .136 & .892 \\
\hline CRM & .809 & .134 & .506 & 6.032 & .000 \\
\hline $\begin{array}{l}\text { Kualitas } \\
\text { Pelayanan }\end{array}$ & .302 & .105 & .241 & 2.873 & .005 \\
\hline
\end{tabular}

Coefficients $^{\mathrm{a}}$

a. Dependent Variable: Keputusan

Pembelian

Sumber: hasil pengelolaan data SPSS 16.0

Berdasarkan tabel di atas penjelasan masing-masing variabel terhadap keputusan pembelian adalah sebagai berikut:

\section{a. Variabel Customer Relationship Management}

Berdasarkan Tabel 4.10 di atas dapat dilihat bahwa nilai $t_{\text {hitung }}$ variabel CRM sebesar 6,032, dimana $t_{\text {hitung }}>t_{\text {tabel }}(6,032$ $>1,984$ ) dengan nilai signifikansi $0,000<$ 0,05. Maka Ho ditolak dan Ha diterima, sehingga dapat disimpulkan bahwa ada 
hubungan positif yang signifikan antara CRM dengan keputusan pembelian.

b. Variabel Kualitas Pelayanan

Berdasarkan Tabel 4.10 di atas dapat dilihat bahwa nilai $t_{\text {hitung }}$ variabel kualitas pelayanan sebesar 2,873, dimana $t_{\text {hitung }}>$ $t_{\text {tabel }}(2,873>1,984)$ dengan nilai signifikansi $0,005<0,05$. Maka Ho ditolak dan Ha diterima, sehingga dapat disimpulkan bahwa ada hubungan positif yang signifikan antara kualitas pelayanan dengan keputusan pembelian.

2. Uji Simultan (Uji F)

Uji $F$ atau uji koefisien regresi digunakan untuk mengetahui apakah secara bersama-sama variabel independen berpengaruh signifikan terhadap variabel dependen. Pengujian menggunakan tingkat signifikansi 0,05. Hasil uji $F$ dapat dilihat sebagai berikut:

Tabel 4.11 Hasil Uji F ANOVA $^{b}$

\begin{tabular}{|l|r|r|r|r|r|}
\hline Model & $\begin{array}{c}\text { Sum of } \\
\text { Squares }\end{array}$ & Df & $\begin{array}{c}\text { Mean } \\
\text { Square }\end{array}$ & F & Sig. \\
\hline 1 Regression & 265.906 & 2 & 132.953 & 32.380 & $.000^{\mathrm{a}}$ \\
Residual & 398.284 & 97 & 4.106 & & \\
Total & 664.190 & 99 & & & \\
\hline
\end{tabular}

a. Predictors: (Constant), Kualitas

Pelayanan, CRM

b. Dependent Variable: Keputusan

Pembelian

Sumber: hasil pengelolaan data SPSS 16,0

Berdasarkan hasil Tabel 4.11 di atas dapat diketahui bahwa nilai $F_{\text {hitung }}>F_{\text {tabel }}$ $(32,380>3,09)$ dengan nilai signifikansi 0,000 $<0,05$ maka dapat disimpulkan bahwa terdapat pengaruh signifikan secara bersama-sama antara CRM $\left(\mathrm{X}_{1}\right)$ dan kualitas pelayanan $\left(\mathrm{X}_{2}\right)$ terhadap keputusan pembelian (Y).

3. Uji Koefisien Determinasi $\left(\mathrm{R}^{2}\right)$

Analisis ini untuk mengetahui seberapa besar kemampuan variabel independen menjelaskan variabel dependen. Dari uji analisis koefisien determinasi diperoleh hasil sebagai berikut:

Tabel 4.12 Hasil Uji Koefisien Determinasi

\begin{tabular}{|l|l|r|r|r|}
\multicolumn{5}{c|}{ Model Summary $^{\text {b }}$} \\
\hline Model & R & R Square & $\begin{array}{l}\text { Adjusted } \\
\text { R Square }\end{array}$ & $\begin{array}{l}\text { Std. Error of } \\
\text { the Estimate }\end{array}$ \\
\hline 1 & $.633^{\mathrm{a}}$ & .400 & .388 & 2.026 \\
\hline
\end{tabular}

a. Predictors: (Constant), Kualitas Pelayanan, CRM

b. Dependent Variable: Keputusan Pembelian

Sumber: hasil pengelolaan data SPSS 16,0

Pada tabel di atas terlihat bahwa nilai $\mathrm{R}$ square sebesar 0,400. Hasil ini menunjukkan bahwa pengaruh CRM dan kualitas pelayanan terhadap keputusan pembelian sebesar $40 \%$ dan sisanya $60 \%$ dipengaruhi oleh faktor-faktor lain diluar variabel yang digunakan dalam penelitian ini.

\section{PEMBAHASAN}

\section{Pengaruh Customer Relationship Management Terhadap Keputusan Pembelian}

Hasil pengujian yang disajikan pada Tabel 4.10 menunjukkan CRM $\left(\mathrm{X}_{1}\right)$ dengan nilai $\mathrm{t}_{\text {hitung }} 6,032>\mathrm{t}_{\text {tabel }} 1,984$ dengan nilai signifikansi $0,000<0,05$, artinya CRM berpengaruh signifikan terhadap keputusan pembelian. Hasil ini mendukung hipotesis bahwa CRM memengaruhi keputusan pembelian. Pengaruh dari CRM terhadap keputusan pembelian hasil analisis menunjukkan bahwa CRM berpengaruh positif dan signifikan terhadap keputusan pembelian. Hal ini menunjukkan bahwa CRM yang dipersepsi baik oleh pelanggan akan tercipta kedekatan antara pelanggan dengan perusahaan. Adanya CRM yang baik juga secara langsung membuat citra perusahaan menjadi terjaga dimana pelanggan akan melihat bahwa perusahaan memiliki reputasi yang terpercaya. Hal ini akan membuat pelanggan menjadi percaya dalam melakukan pembelian di perusahaan NSS tersebut karena merasakan adanya kedekatan dari pihak perusahaan.

Menurut Rahmadewi et. al (2015) hubungan antara CRM dengan keputusan pembelian terletak pada keinginan-keinginan dan pilihan pelanggan atas suatu merek yang merupakan kedekatan pelanggan dengan penyedia jasa/produk. Kedekatan dan kepercayaan pelanggan akan suatu penyedia jasa/produk akan menciptakan kemauan pelanggan untuk menggunakan kembali dan bahkan meningkatkan loyalitas pelanggan terhadap penyedia jasa/produk. Teori penghubung antara CRM dengan keputusan pembelian dikutip dari Rangkuti (2002) yang mengatakan "Apabila pelanggan beranggapan bahwa penyedia jasa tertentu berbeda dengan pesaing. Pembeda keduanya adalah dari CRM yang akan melekat secara terus menerus sehingga dapat membentuk kesetiaan untuk terus menggunakan jasa tersebut". Hasil penelitian ini sama dengan hasil penelitian 
Lisdayanti (2017) yang menyatakan bahwa CRM berpengaruh secara positif dan signifikan terhadap keputusan pembelian.

\section{Pengaruh Kualitas Pelayanan Terhadap Keputusan Pembelian}

Hasil pengujian yang disajikan pada Tabel 4.10 menunjukkan kualitas pelayanan $\left(\mathrm{X}_{2}\right)$ dengan nilai $t_{\text {hitung }} 2,873>t_{\text {tabel }} 1,984$ dengan nilai signifikansi $0,000<0,05$, artinya kualitas pelayanan berpengaruh signifikan terhadap keputusan pembelian. Pengaruh dari kualitas pelayanan terhadap keputusan pembelian hasil analisis menunjukkan bahwa kualitas pelayanan berpengaruh positif dan signifikan terhadap keputusan pembelian. Hal ini menunjukkan bahwa semakin baik layanan yang diberikan oleh perusahaan terhadap para pelanggannya maka akan semakin baik juga persepsi pelanggan terhadap layanan yang diberikan oleh perusahaan. Sebagai pihak yang membeli dan mengkonsumsi produk/jasa, pelangganlah yang menilai tingkat kualitas pelayanan suatu perusahaan.

Menurut Tjiptono, (2004:145) kualitas pelayanan yang baik akan menciptakan kepuasan bagi konsumen. Hal tersebut akan memengaruhi proses pengambilan keputusan pembelian. Apabila konsumen merasa puas akan layanan yang diberikan oleh suatu perusahaan, mereka akan membeli ulang serta memberi rekomendasi kepada orang lain untuk membeli di tempat yang sama. PT Nusantara Surya Sakti yang bergerak dibidang otomotif menyediakan produk dengan kualitas pelayanan yang baik akan memicu konsumen untuk menjatuhkan pilihan di dealer NSS dari pada dealer lain. Sesuai dengan selogan NSS yaitu tercepat, termudah dan terpercaya yang diberikan oleh perusahaan dapat memengaruhi tindakan konsumen dalam pengambilan keputusan pembelian di PT. Nusantara Surya Sakti Sumbawa. Hasil penelitian ini sama dengan hasil penelitian yang dilakukan oleh Siow (2013) yang menyatakan bahwa kualitas pelayanan berpengaruh positif dan signifikan terhadap keputusan pembelian.

\section{Pengaruh Customer Relationship Management dan Kualitas Pelayanan Terhadap Keputusan Pembelian}

Berdasarkan hasil analisis data diketahui bahwa variabel customer relationship management dan kualitas pelayanan berpengaruh secara simultan terhadap keputusan pembelian.

Dalam memengaruhi keputusan pembelian, sebuah perusahaan harus dapat memberikan layanan terbaik kepada para konsumennya. Selain itu, membangun hubungan dengan pelanggan juga memiliki peran penting dalam sebuah perusahaan. Usaha dalam mendapatkan dan mempertahankan pelanggan memang tidaklah mudah. Oleh karena itu, perlu beberapa tahapan, mulai dari kesan pertama pelanggan sampai dengan memperoleh pelanggan yang setia. Cara memengaruhi keputusan pembelian konsumen, NSS harus terus berusaha meningkatkan customer relationship management serta kualitas pelayanan yang diberikan. Sehingga pelanggan akan merasa yakin untuk melakukan pembelian di NSS.

Adanya pengaruh positif dan signifikan variabel customer relationship management dan kualitas pelayanan ini juga didukung dengan hasil R Square pada Koefisien Determinasi sebesar $40 \%$. Hal ini mengindikasikan bahwa sebesar $40 \%$ variabel independen CRM dan kualitas pelayanan dapat memengaruhi keputusan pembelian, sedangkan sisanya $60 \%$ dipengaruhi oleh faktorfaktor lain diluar variabel yang digunakan dalam penelitian ini.

Faktor lain yang dapat memengaruhi keputusan pembelian antara lain: harga. Harga merupakan sejumlah uang yang dibebankan atas suatu produk/jasa, atau jumlah dari nilai yang ditukar konsumen atas manfaat-manfaat karena memiliki atau menggunakan produk/jasa tersebut. Harga juga memiliki manfaat yang besar terhadap tingkat kepuasan konsumen karena dengan harga yang terjangkau maka konsumen merasa puas sedangkan penetepan harga yang tidak sesuai akan berpengaruh pada konsumen. Hal ini menunjukkan bahwa harga menjadi salah satu pertimbangan konsumen dalam memutuskan akan membeli atau tidak suatu produk. Hasil penelitian yang menunjukkan bahwa harga berpengaruh terhadap keputusan pembelian dilakukan oleh Lotulung et al (2015).

\section{PENUTUP}

\section{Kesimpulan}

Berdasarkan analisis dan pembahasan hasil penelitian yang telah dilakukan, maka dapat ditarik kesimpulan sebagai berikut:

1. Customer relationship management memberikan pengaruh yang positif dan signifikan terhadap keputusan pembelian produk PT. Nusantara Surya Sakti Sumbawa. Hal ini menunjukkan bahwa semakin baik hubungan perusahaan dengan pelanggan yang tercipta tentu bisa membuat pelanggan percaya dalam melakukan pembelian di perusahaan NSS.

2. Kualitas pelayanan memberikan pengaruh yang positif dan signifikan terhadap keputusan pembelian produk PT. Nusantara Surya Sakti Sumbawa. Artinya, jika kualitas pelayanan meningkat perusahaan dengan mudah menarik pelanggan untuk melakukan pembelian. 
3. Customer relationship management dan kualitas pelayanan mempunyai pengaruh secara bersama-sama terhadap keputusan pembelian. Hal ini menunjukkan, apabila peningkatan customer relationship management dan kualitas pelayanan secara terus-menerus dan bersama-sama akan memberikan pengaruh yang positif terhadap keputusan pembelian.

4. Pada penelitian ini customer relationship management dan kualitas pelayanan hanya mampu memengaruhi keputusan pembelian sebesar $40 \%$, sedangkan sisanya $60 \%$ dipengaruhi oleh variabel lain diluar variabel yang digunakan dalam penelitian.

\section{Saran}

1. Bagi peneliti selanjutnya, diharapkan penelitian ini dapat menjadi referensi dan masukan untuk menambah wawasan. Peneliti menyarankan untuk menambah jumlah variabel dan jumlah responden agar dapat memberikan informasi terbaru.

2. Bagi perusahaan diharapkan agar tetap menjaga, meningkatkan dan mempertahankan customer relationship management dan kualitas pelayanan yang selama ini dilakukan.

\section{REFERENSI}

Assauri, Sofyan. (2012). Strategi Marketing. Jakarta: PT Raja Garfindo Persada

Gordon, Ian. (2002). Best Practices: Customer Relationship Management. Ivey Business Journal, Vol. 8 No. 2

Hasan, Ali. (2014). Marketing dan Kasus - Kasus Pilihan. Cetakan ke-2. Yogyakarta: CAPS

Imasari, Kartika dan Nursalin, Kezia Kurniawati. (2011). Pengaruh Customer Relationship Management Terhadap Loyalitas Pelanggan Pada PT. BCA Tbk. Fokus Ekonomi, Vol. 10, No.3 Hal. 183-192

Kalalo, Rinny E. (2013). Customer Relationship Management dan kualitas Pelayanan Pengaruhnya Terhadap Loyalitas Konsumen PT. Matahari Dept. Store, Manado. EMBA, Vol. 1, No. 4, Hal 1553-1561

Kotler, Philip dan Keller, Kevin Lane. (2009). Manajemen Pemasaran Edisi 13 Jilid 1. Jakarta: Erlangga
Lerbin, R Aritonang R. (2007). Riset Pemasaran: Teori \& Praktik. Bogor: Ghalia Indonesia

Lisdayanti, Annisa. (2017). Pengaruh Lokasi, Store Atmosphere, Harga dan CRM Terhadap Keputusan Pembelian Konsumen Pada Milk Bar Bandung. Akuntansi Manajemen dan Ekonomi, Vol. 19, No.2

Lotulung, Selvany Chichilia; Lapian, Joyce; dan Moniharapon, Silcyjeova. (2015). Pengaruh Kualitas Produk, Harga dan WOM (Word Of Mouth) Terhadap Keputusan Pembelian Handphone Evercross Pada CV. Tristar Jaya Globalindo Manado. EMBA, Vol. 3 No. 3, Hal. 817-826.

Lupiyoadi, Rahmat. (2001). Pemasaran Jasa. Jakarta: Salemba Empat

Rahmadewi, Triyana; Farida, Naili; dan Dewi, Reni Sinta. (2015). Pengaruh CRM dan Customer Experience Terhadap Keputusan Pembelian Ulang Melalui Brand Trust Pada PT. Nasmoco Pemuda. Ilmu Administrasi Bisnis, Vol. 4, No.3

Rangkuti, Feddy. (2002). The Power of Brands, Teknik Mengelola Brand Equity dan Strategi Pengembangan Merek. Jakarta: Gramedia Pustaka

Sangadji, M.E dan Sopiah. (2013). Perilaku Konsumen: Himpunan Jurnal Penelitian. Yogyakarta: Andi

Sanusi, Anwar. (2011). Metodologi Penelitian Bisnis. Malang: Salemba Empat

Siow, Natalia. (2013). Kualitas Layanan dan Kepercayaan Pelanggan Pengaruhnya Terhadap Keputusan Pembelian Sepeda Motor Suzuki Satria FU150 Di Kota Manado. EMBA, Vol. 1, No.3, Hal. 1069-1078

Siregar, Sofyan. (2013). Metode Penelitian Kuantitatif. Jakarta: Kencana

Sugiyono. (2015). Metode Penelitian Kuantitatif, Kualitatif $R$ \& D. Bandung: Alfabeta

Sunyoto, D. (2011). Metodologi Penelitian Ekonomi. Yogyakarta: CAPS

Tjiptono, Fandy. (2004). Pemasaran Jasa. Malang: Bayu Media

Widiyanto, Ibnu, (2008). Pointer: Metodologi Penelitian. Semarang: BP UNDIP 
Wirawan, Winanto. (2008). Pengaruh Customer Relationship Management (CRM) Terhadap Loyalitas Pelanggan PT. Astra Internasional TBK. Toyota (Auto 2000) di Kota Bandung. Tugas Akhir Program Sarjana Ekonomi Program Studi Manajemen Fakultas Bisnis dan Manajemen Universitas Widyatama.

\section{INTERNET}

PT. Nusantara Surya Sakti. (2017). "Sejarah PT. Nusantara Surya Sakti dan NSS Express" (Online) (http://www.nssexpress.co.id/about_us, diakses pada 1 mei 2018 pukul 10.27) 


\section{KUESIONER PENELITIAN}

Responden yang terhormat,

Berikut ini saya sampaikan kuesioner penelitian mengenai "Pengaruh Customer Relationship Management dan Kualitas Pelayanan Terhadap Keputusan Pembelian Produk PT. Nusantara Surya Sakti Sumbawa”.

Maksud dari penyampaian kuesioner ini berkaitan dengan penelitian yang saya lakukan maka dari itu saya mohon kesediaan Bapak/Ibu/Saudara/i untuk dapat mengisi kuesioner penelitian ini. Saya berharap Bapak/Ibu/Saudara/i dapat mengisi kuesioner ini dengan jujur dan benar. Jawaban yang Bapak/Ibu/Saudara/i berikan akan dijamin kerahasiaannya dan hanya digunakan untuk kepentingan ilmiah.

Atas bantuan dan kesediaan Bapak/Ibu/Saudara/i, saya ucapkan terima kasih.

Peneliti

(Dini Asraini)

14.01.031.014 


\section{KUESIONER PENELITIAN}

Petunjuk Pengisian:

Berilah tanda checklist $(\sqrt{ })$ pada salah satu jawaban

A. Identitas Responden

1. Nama

2. Jenis Kelamin :

$\square$ Laki-laki

$\square$ Perempuan

3. Usia

$\square$ 17-25

$\square 35-43$

$\square$ 26-34

$\square>44$

4. Pekerjaan :

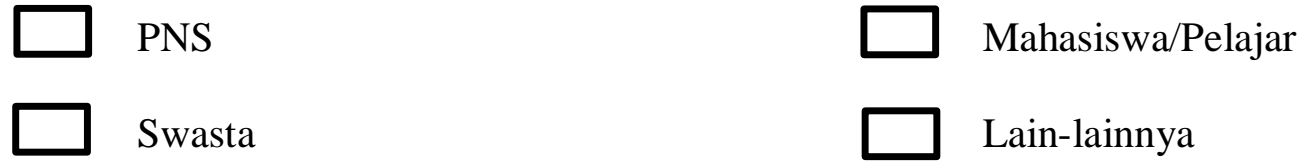

$\square$ Wirausaha

B. Kriteria Penilaian

Berilah tanda checklist $(\sqrt{ })$ untuk jawaban dari masing-masing penyataan sesuai dengan pendapat anda. Bila anda ingin memperbaiki jawaban yang telah anda buat, maka berilah tanda sama dengan $(=)$ kemudian pilih dan berilah tanda $(\sqrt{ })$ pada jawaban yang baru dan benar.

Ketentuan:

- $\quad$ Sangat Tidak Setuju (STS) $=1$

- Tidak Setuju (TS) $\quad=2$

- $\begin{array}{cc}\text { Setuju (S) } & =3\end{array}$

- Sangat Setuju (SS) $\quad=4$ 
Customer Relationship Management $\left(\mathrm{X}_{1}\right)$

(Manajemen Hubungan Pelanggan)

\begin{tabular}{|c|c|c|c|c|c|}
\hline No & Pernyataan & STS & $\mathrm{TS}$ & S & SS \\
\hline 1. & $\begin{array}{l}\text { Informasi yang diberikan NSS melalui media } \\
\text { elektronik (internet, e-mail, SMS, dll) mudah } \\
\text { diperoleh }\end{array}$ & & & & \\
\hline 2. & $\begin{array}{l}\text { Penggunaan sistem aplikasi database pelanggan yang } \\
\text { diterapkan oleh NSS sudah baik }\end{array}$ & & & & \\
\hline 3. & $\begin{array}{l}\text { NSS memberikan kemudahan terhadap pelanggan } \\
\text { dalam melakukan transaksi }\end{array}$ & & & & \\
\hline 4. & $\begin{array}{l}\text { Penanganan keluhan yang dilakukan oleh NSS sudah } \\
\text { baik }\end{array}$ & & & & \\
\hline 5. & $\begin{array}{l}\text { Kemampuan yang dimiliki karyawan NSS dalam } \\
\text { menjaga hubungan baik dengan pelanggan sudah baik }\end{array}$ & & & & \\
\hline 6. & $\begin{array}{l}\text { Profesionalisme yang dimiliki karyawan NSS sudah } \\
\text { baik }\end{array}$ & & & & \\
\hline
\end{tabular}

\section{Kualitas Pelayanan $\left(\mathbf{X}_{2}\right)$}

\begin{tabular}{|c|c|c|c|c|c|}
\hline No & Penyataan & STS & $\mathrm{TS}$ & $\mathrm{S}$ & SS \\
\hline 1. & Ketersediaan ruang tunggu yang bersih dan nyaman & & & & \\
\hline 2. & $\begin{array}{l}\text { Kebersihan di lingkungan NSS di pelihara dengan } \\
\text { baik }\end{array}$ & & & & \\
\hline 3. & $\begin{array}{l}\text { Karyawan NSS memberikan layanan tepat pada } \\
\text { waktunya }\end{array}$ & & & & \\
\hline 4. & Pelayanan sesuai dengan janji yang di berikan & & & & \\
\hline 5. & Karyawan NSS ramah dalam melayani pelanggan & & & & \\
\hline 6. & $\begin{array}{l}\text { Karyawan NSS siap membantu pelanggan bila } \\
\text { mengalami kesulitan }\end{array}$ & & & & \\
\hline
\end{tabular}




\begin{tabular}{|r|l|l|l|l|l|}
\hline 7. & $\begin{array}{l}\text { Karyawan mampu menjawab setiap pertanyaan } \\
\text { pelanggan }\end{array}$ & & & \\
\hline 8. & Karyawan mudah di hubungi oleh pelanggan & & & & \\
\hline 9. & Pelayanan pada pelanggan tidak membedakan status & & & & \\
\hline
\end{tabular}

\section{Keputusan Pembelian (Y)}

\begin{tabular}{|c|c|c|c|c|c|}
\hline No & Pernyataan & STS & $\mathrm{TS}$ & $\mathrm{S}$ & SS \\
\hline 1. & $\begin{array}{l}\text { Saya membeli sepeda motor karena merasa butuh } \\
\text { kendaraan untuk bepergian }\end{array}$ & & & & \\
\hline 2. & $\begin{array}{l}\text { Saya mencari informasi mengenai sepeda motor } \\
\text { NSS sebelum memutuskan untuk membeli }\end{array}$ & & & & \\
\hline 3. & $\begin{array}{l}\text { saya memutuskan untuk membeli motor di NSS } \\
\text { setelah mengevaluasi beberapa alternatif }\end{array}$ & & & & \\
\hline 4. & $\begin{array}{l}\text { Saya merasa yakin dengan membeli sepeda motor di } \\
\text { NSS }\end{array}$ & & & & \\
\hline 5. & $\begin{array}{l}\text { Saya merasa puas setelah melakukan pembelian } \\
\text { produk sepeda motor di NSS }\end{array}$ & & & & \\
\hline 6. & $\begin{array}{l}\text { Saya berniat untuk melakukan pembelian ulang } \\
\text { terhadap produk NSS }\end{array}$ & & & & \\
\hline 7. & $\begin{array}{l}\text { Saya akan mempromosikan produk NSS kepada } \\
\text { keluarga dan teman saya untuk melakukan } \\
\text { pembelian sepeda motor di NSS }\end{array}$ & & & & \\
\hline
\end{tabular}




\section{Data Kuesioner}

\begin{tabular}{|c|c|c|c|c|c|c|c|c|c|c|c|c|c|c|c|c|c|c|c|c|c|c|c|c|c|}
\hline No & $\begin{array}{c}\text { CRM } \\
1 \\
\end{array}$ & $\begin{array}{c}\text { CRM } \\
2 \\
\end{array}$ & $\begin{array}{c}\text { CRM } \\
3 \\
\end{array}$ & $\begin{array}{c}\text { CRM } \\
4 \\
\end{array}$ & $\begin{array}{c}\text { CRM } \\
5 \\
\end{array}$ & $\begin{array}{c}\text { CRM } \\
6\end{array}$ & $\begin{array}{c}\text { TOTA } \\
\mathrm{L}\end{array}$ & $\begin{array}{c}\mathrm{KL} \\
1 \\
\end{array}$ & $\begin{array}{c}\mathrm{KL} \\
2 \\
\end{array}$ & $\begin{array}{c}\mathrm{KL} \\
3 \\
\end{array}$ & $\begin{array}{c}\mathrm{KL} \\
4 \\
\end{array}$ & $\begin{array}{c}\mathrm{KL} \\
5 \\
\end{array}$ & $\begin{array}{c}\mathrm{KL} \\
6 \\
\end{array}$ & $\begin{array}{c}\mathrm{KL} \\
7 \\
\end{array}$ & $\begin{array}{c}\mathrm{KL} \\
8 \\
\end{array}$ & $\begin{array}{c}\mathrm{KL} \\
9 \\
\end{array}$ & $\begin{array}{c}\text { TOTA } \\
\mathrm{L} \\
\end{array}$ & $\begin{array}{c}\mathrm{KP} \\
1 \\
\end{array}$ & $\begin{array}{c}\mathrm{KP} \\
2 \\
\end{array}$ & $\begin{array}{c}K P \\
3 \\
\end{array}$ & $\begin{array}{c}\mathrm{KP} \\
4 \\
\end{array}$ & $\begin{array}{c}\mathrm{KP} \\
5 \\
\end{array}$ & $\begin{array}{c}\text { KP } \\
6 \\
\end{array}$ & $\begin{array}{c}\mathrm{KP} \\
7 \\
\end{array}$ & $\begin{array}{c}\text { TOTA } \\
\mathrm{L}\end{array}$ \\
\hline 1 & 3 & 3 & 4 & 3 & 3 & 3 & 19 & 2 & 4 & 3 & 3 & 3 & 3 & 3 & 2 & 3 & 26 & 2 & 3 & 4 & 3 & 3 & 4 & 3 & 22 \\
\hline 2 & 3 & 3 & 3 & 3 & 3 & 3 & 18 & 3 & 3 & 3 & 3 & 3 & 3 & 3 & 3 & 3 & 27 & 4 & 4 & 4 & 4 & 3 & 3 & 3 & 25 \\
\hline 3 & 3 & 3 & 3 & 1 & 3 & 3 & 16 & 1 & 3 & 3 & 1 & 3 & 3 & 2 & 2 & 3 & 21 & 2 & 3 & 3 & 2 & 3 & 3 & 4 & 20 \\
\hline 4 & 3 & 4 & 3 & 3 & 3 & 3 & 19 & 3 & 2 & 3 & 3 & 3 & 3 & 3 & 3 & 3 & 26 & 3 & 3 & 3 & 3 & 3 & 3 & 3 & 21 \\
\hline 5 & 3 & 3 & 3 & 3 & 3 & 3 & 18 & 3 & 2 & 3 & 3 & 3 & 3 & 3 & 3 & 3 & 26 & 3 & 3 & 3 & 3 & 3 & 3 & 3 & 21 \\
\hline 7 & 3 & 3 & 3 & 2 & 3 & 3 & 17 & 3 & 2 & 3 & 2 & 3 & 3 & 2 & 1 & 3 & 22 & 2 & 3 & 3 & 3 & 3 & 3 & 3 & 20 \\
\hline 8 & 3 & 3 & 4 & 3 & 3 & 3 & 19 & 3 & 3 & 4 & 3 & 3 & 3 & 3 & 2 & 3 & 27 & 3 & 3 & 3 & 3 & 4 & 4 & 4 & 24 \\
\hline 9 & 3 & 3 & 3 & 2 & 3 & 3 & 17 & 2 & 2 & 3 & 2 & 3 & 3 & 2 & 3 & 3 & 23 & 2 & 3 & 3 & 2 & 2 & 3 & 3 & 18 \\
\hline 10 & 2 & 3 & 2 & 3 & 2 & 2 & 14 & 2 & 3 & 2 & 3 & 2 & 2 & 3 & 3 & 3 & 23 & 2 & 3 & 3 & 3 & 3 & 2 & 2 & 18 \\
\hline 11 & 3 & 3 & 3 & 3 & 3 & 3 & 18 & 3 & 2 & 3 & 3 & 3 & 3 & 3 & 3 & 3 & 26 & 3 & 3 & 3 & 3 & 3 & 3 & 3 & 21 \\
\hline 12 & 3 & 3 & 4 & 3 & 4 & 3 & 20 & 4 & 3 & 4 & 2 & 4 & 2 & 3 & 3 & 3 & 28 & 4 & 4 & 4 & 4 & 4 & 4 & 4 & 28 \\
\hline 14 & 3 & 2 & 3 & 3 & 3 & 3 & 17 & 3 & 3 & 3 & 3 & 3 & 3 & 2 & 4 & 3 & 27 & 2 & 3 & 3 & 3 & 3 & 3 & 3 & 20 \\
\hline 15 & 4 & 3 & 3 & 4 & 4 & 4 & 22 & 3 & 4 & 3 & 3 & 2 & 4 & 3 & 2 & 3 & 27 & 4 & 4 & 4 & 4 & 3 & 4 & 4 & 27 \\
\hline 16 & 3 & 3 & 4 & 3 & 3 & 3 & 19 & 4 & 3 & 2 & 3 & 3 & 3 & 3 & 3 & 3 & 27 & 2 & 3 & 4 & 3 & 3 & 4 & 3 & 22 \\
\hline 17 & 3 & 3 & 3 & 3 & 3 & 3 & 18 & 3 & 3 & 3 & 3 & 3 & 3 & 3 & 3 & 3 & 27 & 4 & 4 & 4 & 4 & 3 & 3 & 3 & 25 \\
\hline 18 & 3 & 2 & 3 & 1 & 3 & 3 & 15 & 3 & 3 & 3 & 1 & 3 & 3 & 4 & 3 & 3 & 26 & 2 & 3 & 3 & 2 & 3 & 3 & 4 & 20 \\
\hline 19 & 3 & 2 & 3 & 3 & 3 & 3 & 17 & 3 & 2 & 3 & 3 & 3 & 3 & 3 & 2 & 3 & 25 & 3 & 3 & 3 & 3 & 3 & 3 & 3 & 21 \\
\hline 20 & 3 & 3 & 3 & 3 & 3 & 3 & 18 & 3 & 2 & 3 & 3 & 3 & 3 & 3 & 3 & 3 & 26 & 3 & 3 & 3 & 3 & 3 & 3 & 3 & 21 \\
\hline 21 & 4 & 3 & 4 & 3 & 3 & 4 & 21 & 3 & 4 & 4 & 3 & 3 & 4 & 2 & 2 & 3 & 28 & 4 & 4 & 4 & 4 & 4 & 4 & 4 & 28 \\
\hline 22 & 3 & 3 & 3 & 2 & 3 & 3 & 17 & 3 & 2 & 3 & 2 & 3 & 3 & 3 & 2 & 4 & 25 & 2 & 3 & 3 & 3 & 3 & 3 & 3 & 20 \\
\hline 23 & 3 & 2 & 4 & 3 & 3 & 3 & 18 & 3 & 3 & 4 & 3 & 3 & 3 & 3 & 3 & 2 & 27 & 3 & 3 & 3 & 3 & 4 & 4 & 4 & 24 \\
\hline 24 & 3 & 2 & 3 & 2 & 3 & 3 & 16 & 2 & 2 & 3 & 2 & 3 & 3 & 2 & 3 & 4 & 24 & 2 & 3 & 3 & 2 & 2 & 3 & 3 & 18 \\
\hline 25 & 2 & 2 & 2 & 3 & 2 & 2 & 13 & 2 & 3 & 2 & 3 & 2 & 2 & 2 & 4 & 2 & 22 & 2 & 3 & 1 & 3 & 3 & 2 & 2 & 16 \\
\hline
\end{tabular}




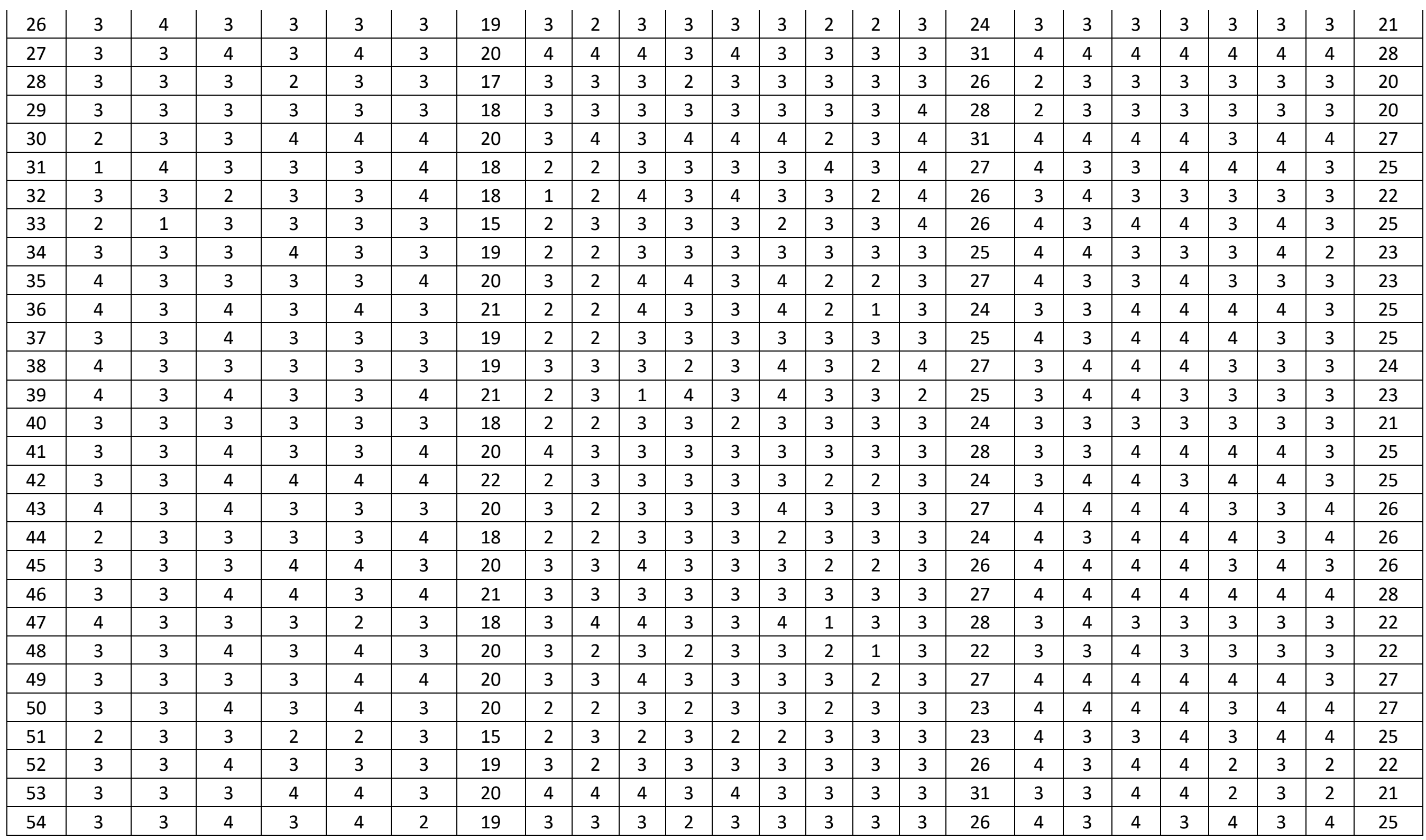




\begin{tabular}{|c|c|c|c|c|c|c|c|c|c|c|c|c|c|c|c|c|c|c|c|c|c|c|c|c|c|}
\hline 55 & 3 & 4 & 2 & 3 & 3 & 3 & 18 & 3 & 3 & 3 & 3 & 3 & 3 & 4 & 4 & 3 & 29 & 4 & 3 & 3 & 3 & 4 & 3 & 4 & 24 \\
\hline 56 & 4 & 3 & 3 & 4 & 3 & 3 & 20 & 3 & 4 & 3 & 3 & 3 & 4 & 3 & 2 & 3 & 28 & 3 & 4 & 4 & 3 & 3 & 4 & 3 & 24 \\
\hline 57 & 3 & 3 & 3 & 3 & 3 & 3 & 18 & 4 & 4 & 4 & 3 & 3 & 3 & 3 & 3 & 3 & 30 & 3 & 4 & 3 & 4 & 4 & 4 & 3 & 25 \\
\hline 58 & 3 & 3 & 3 & 3 & 3 & 4 & 19 & 3 & 3 & 3 & 3 & 3 & 3 & 3 & 3 & 3 & 27 & 4 & 3 & 3 & 4 & 3 & 2 & 3 & 22 \\
\hline 59 & 3 & 2 & 3 & 3 & 3 & 4 & 18 & 3 & 3 & 3 & 1 & 3 & 3 & 4 & 3 & 3 & 26 & 4 & 3 & 3 & 3 & 3 & 4 & 3 & 23 \\
\hline 60 & 3 & 3 & 4 & 3 & 3 & 3 & 19 & 4 & 4 & 4 & 3 & 3 & 3 & 3 & 2 & 3 & 29 & 4 & 3 & 4 & 4 & 3 & 3 & 3 & 24 \\
\hline 61 & 3 & 3 & 4 & 4 & 4 & 3 & 21 & 3 & 3 & 3 & 3 & 3 & 3 & 3 & 3 & 3 & 27 & 3 & 4 & 3 & 4 & 4 & 4 & 3 & 25 \\
\hline 62 & 3 & 3 & 3 & 3 & 4 & 3 & 19 & 3 & 3 & 3 & 1 & 3 & 3 & 2 & 3 & 3 & 24 & 3 & 3 & 4 & 3 & 3 & 3 & 3 & 22 \\
\hline 63 & 3 & 4 & 3 & 3 & 3 & 3 & 19 & 3 & 2 & 3 & 3 & 3 & 3 & 3 & 3 & 3 & 26 & 4 & 3 & 3 & 4 & 3 & 3 & 3 & 23 \\
\hline 64 & 3 & 3 & 4 & 3 & 4 & 3 & 20 & 3 & 2 & 3 & 3 & 3 & 3 & 3 & 3 & 3 & 26 & 3 & 4 & 4 & 4 & 3 & 4 & 4 & 26 \\
\hline 65 & 4 & 3 & 4 & 3 & 3 & 3 & 20 & 3 & 4 & 4 & 3 & 3 & 4 & 1 & 3 & 3 & 28 & 3 & 3 & 4 & 4 & 4 & 4 & 3 & 25 \\
\hline 66 & 3 & 3 & 3 & 3 & 4 & 3 & 19 & 3 & 2 & 3 & 2 & 3 & 3 & 2 & 3 & 3 & 24 & 4 & 3 & 3 & 3 & 3 & 3 & 3 & 22 \\
\hline 67 & 3 & 3 & 3 & 3 & 3 & 2 & 17 & 3 & 3 & 4 & 3 & 3 & 3 & 3 & 2 & 3 & 27 & 3 & 3 & 3 & 4 & 3 & 4 & 3 & 23 \\
\hline 68 & 3 & 3 & 3 & 3 & 3 & 3 & 18 & 2 & 2 & 3 & 2 & 3 & 3 & 2 & 3 & 3 & 23 & 3 & 3 & 4 & 4 & 3 & 4 & 3 & 24 \\
\hline 70 & 3 & 3 & 3 & 4 & 3 & 2 & 18 & 3 & 2 & 3 & 3 & 3 & 3 & 2 & 3 & 2 & 24 & 3 & 4 & 4 & 4 & 4 & 3 & 4 & 26 \\
\hline 71 & 3 & 3 & 4 & 3 & 3 & 2 & 18 & 4 & 4 & 4 & 3 & 4 & 3 & 3 & 3 & 3 & 31 & 3 & 4 & 4 & 3 & 4 & 3 & 3 & 24 \\
\hline 72 & 3 & 3 & 4 & 3 & 3 & 3 & 19 & 3 & 3 & 3 & 2 & 3 & 3 & 2 & 3 & 3 & 25 & 4 & 4 & 4 & 4 & 3 & 3 & 3 & 25 \\
\hline 73 & 3 & 3 & 4 & 4 & 4 & 3 & 21 & 3 & 3 & 3 & 3 & 3 & 3 & 3 & 2 & 3 & 26 & 3 & 3 & 3 & 4 & 3 & 3 & 3 & 22 \\
\hline 74 & 3 & 3 & 4 & 3 & 3 & 4 & 20 & 3 & 3 & 3 & 1 & 3 & 3 & 3 & 3 & 3 & 25 & 3 & 3 & 4 & 3 & 4 & 3 & 3 & 23 \\
\hline 75 & 3 & 4 & 3 & 3 & 3 & 4 & 20 & 3 & 2 & 3 & 3 & 3 & 3 & 2 & 3 & 3 & 25 & 4 & 4 & 3 & 4 & 4 & 4 & 3 & 26 \\
\hline 76 & 3 & 3 & 4 & 3 & 3 & 3 & 19 & 3 & 2 & 3 & 3 & 3 & 3 & 3 & 3 & 3 & 26 & 3 & 3 & 4 & 3 & 4 & 4 & 3 & 24 \\
\hline 77 & 4 & 3 & 4 & 3 & 3 & 3 & 20 & 3 & 4 & 3 & 3 & 3 & 3 & 3 & 3 & 3 & 28 & 4 & 4 & 3 & 4 & 3 & 4 & 4 & 26 \\
\hline 78 & 3 & 3 & 3 & 3 & 3 & 4 & 19 & 4 & 3 & 4 & 3 & 3 & 3 & 3 & 2 & 3 & 28 & 3 & 3 & 3 & 4 & 3 & 4 & 4 & 24 \\
\hline 79 & 3 & 3 & 4 & 3 & 3 & 3 & 19 & 3 & 3 & 3 & 3 & 3 & 3 & 3 & 3 & 3 & 27 & 4 & 3 & 4 & 3 & 4 & 4 & 3 & 25 \\
\hline 80 & 3 & 2 & 4 & 3 & 3 & 3 & 18 & 3 & 3 & 3 & 1 & 3 & 3 & 3 & 3 & 3 & 25 & 4 & 3 & 4 & 3 & 3 & 3 & 3 & 23 \\
\hline 81 & 3 & 3 & 3 & 3 & 4 & 3 & 19 & 4 & 3 & 4 & 3 & 3 & 2 & 4 & 3 & 3 & 29 & 4 & 4 & 4 & 4 & 3 & 4 & 3 & 26 \\
\hline 82 & 3 & 3 & 3 & 4 & 3 & 4 & 20 & 3 & 3 & 3 & 3 & 3 & 3 & 3 & 2 & 3 & 26 & 4 & 4 & 4 & 3 & 3 & 4 & 4 & 26 \\
\hline
\end{tabular}




\begin{tabular}{|c|c|c|c|c|c|c|c|c|c|c|c|c|c|c|c|c|c|c|c|c|c|c|c|c|c|}
\hline 84 & 3 & 4 & 4 & 3 & 3 & 4 & 21 & 3 & 2 & 3 & 3 & 3 & 3 & 2 & 3 & 3 & 25 & 3 & 3 & 4 & 4 & 4 & 4 & 4 & 26 \\
\hline 85 & 3 & 3 & 3 & 3 & 3 & 2 & 17 & 3 & 2 & 3 & 3 & 3 & 3 & 3 & 3 & 3 & 26 & 3 & 4 & 4 & 3 & 4 & 3 & 3 & 24 \\
\hline 86 & 3 & 2 & 3 & 3 & 3 & 4 & 18 & 3 & 2 & 3 & 3 & 3 & 3 & 4 & 4 & 3 & 28 & 3 & 3 & 3 & 4 & 3 & 4 & 4 & 24 \\
\hline 88 & 3 & 3 & 4 & 4 & 4 & 3 & 21 & 3 & 4 & 4 & 3 & 3 & 3 & 3 & 3 & 3 & 29 & 4 & 3 & 3 & 4 & 3 & 3 & 2 & 22 \\
\hline 89 & 3 & 3 & 3 & 4 & 4 & 3 & 20 & 3 & 2 & 3 & 2 & 3 & 3 & 3 & 3 & 3 & 25 & 3 & 4 & 3 & 3 & 3 & 2 & 2 & 20 \\
\hline 90 & 3 & 2 & 4 & 3 & 3 & 3 & 18 & 3 & 3 & 2 & 3 & 3 & 3 & 4 & 3 & 3 & 27 & 4 & 3 & 4 & 3 & 3 & 2 & 3 & 22 \\
\hline 91 & 3 & 2 & 3 & 3 & 3 & 3 & 17 & 2 & 2 & 3 & 2 & 3 & 3 & 3 & 2 & 3 & 23 & 3 & 3 & 3 & 4 & 3 & 3 & 3 & 22 \\
\hline 92 & 2 & 2 & 3 & 4 & 3 & 3 & 17 & 2 & 3 & 2 & 3 & 2 & 2 & 3 & 3 & 3 & 23 & 2 & 3 & 3 & 3 & 2 & 2 & 2 & 17 \\
\hline 93 & 3 & 4 & 3 & 4 & 3 & 2 & 19 & 3 & 2 & 3 & 3 & 3 & 3 & 2 & 3 & 3 & 25 & 4 & 3 & 4 & 4 & 3 & 3 & 3 & 24 \\
\hline 94 & 3 & 3 & 3 & 3 & 3 & 4 & 19 & 3 & 3 & 3 & 3 & 4 & 3 & 3 & 3 & 3 & 28 & 4 & 3 & 4 & 4 & 4 & 4 & 4 & 27 \\
\hline 95 & 3 & 3 & 4 & 3 & 3 & 3 & 19 & 3 & 3 & 3 & 2 & 3 & 3 & 3 & 3 & 3 & 26 & 4 & 4 & 4 & 4 & 4 & 3 & 4 & 27 \\
\hline 96 & 3 & 3 & 3 & 3 & 3 & 3 & 18 & 3 & 3 & 3 & 3 & 3 & 3 & 3 & 2 & 3 & 26 & 3 & 3 & 4 & 4 & 3 & 3 & 3 & 23 \\
\hline 97 & 4 & 3 & 4 & 4 & 3 & 3 & 21 & 3 & 3 & 3 & 4 & 3 & 4 & 3 & 3 & 3 & 29 & 3 & 4 & 4 & 3 & 3 & 4 & 3 & 24 \\
\hline 99 & 3 & 3 & 3 & 3 & 4 & 3 & 19 & 3 & 3 & 3 & 3 & 2 & 3 & 4 & 3 & 3 & 27 & 3 & 4 & 3 & 3 & 3 & 3 & 3 & 22 \\
\hline 100 & 3 & 4 & 3 & 3 & 4 & 3 & 20 & 3 & 2 & 3 & 3 & 3 & 3 & 3 & 2 & 3 & 25 & 3 & 3 & 4 & 4 & 4 & 4 & 3 & 25 \\
\hline
\end{tabular}




\section{Hasil Uji Validitas dan Reliabilitas}

1. Uji Validitas

a. Customer Relationship Management

\section{Correlations}

\begin{tabular}{|c|c|c|c|c|c|c|c|c|}
\hline & & CRM1 & CRM2 & CRM3 & CRM4 & CRM5 & CRM6 & TOTAL \\
\hline \multirow[t]{3}{*}{ CRM1 } & Pearson Correlation & 1 & .242 & .090 & .300 & .226 & .136 & $.616^{\star *}$ \\
\hline & Sig. (2-tailed) & & .198 & .637 & .107 & .229 & .475 & .000 \\
\hline & $\mathrm{N}$ & 30 & 30 & 30 & 30 & 30 & 30 & 30 \\
\hline \multirow[t]{3}{*}{ CRM2 } & Pearson Correlation & .242 & 1 & -.022 & $.389^{*}$ & .079 & .228 & $.616^{* *}$ \\
\hline & Sig. (2-tailed) & .198 & & .906 & .034 & .679 & .226 & .000 \\
\hline & $\mathrm{N}$ & 30 & 30 & 30 & 30 & 30 & 30 & 30 \\
\hline \multirow[t]{3}{*}{ CRM3 } & Pearson Correlation & .090 & -.022 & 1 & -.047 & .157 & $.517^{* *}$ & $.445^{*}$ \\
\hline & Sig. (2-tailed) & .637 & .906 & & .805 & .407 & .003 & .014 \\
\hline & $\mathrm{N}$ & 30 & 30 & 30 & 30 & 30 & 30 & 30 \\
\hline \multirow[t]{3}{*}{ CRM4 } & Pearson Correlation & .300 & $.389^{*}$ & -.047 & 1 & .062 & .155 & $.594^{* *}$ \\
\hline & Sig. (2-tailed) & .107 & .034 & .805 & & .745 & .413 & .001 \\
\hline & $\mathrm{N}$ & 30 & 30 & 30 & 30 & 30 & 30 & 30 \\
\hline \multirow[t]{3}{*}{ CRM5 } & Pearson Correlation & .226 & .079 & .157 & .062 & 1 & .345 & $.456^{*}$ \\
\hline & Sig. (2-tailed) & .229 & .679 & .407 & .745 & & .062 & .011 \\
\hline & $\mathrm{N}$ & 30 & 30 & 30 & 30 & 30 & 30 & 30 \\
\hline \multirow[t]{3}{*}{ CRM6 } & Pearson Correlation & .136 & .228 & $.517^{\star *}$ & .155 & .345 & 1 & $.669^{* *}$ \\
\hline & Sig. (2-tailed) & .475 & .226 & .003 & .413 & .062 & & .000 \\
\hline & $\mathrm{N}$ & 30 & 30 & 30 & 30 & 30 & 30 & 30 \\
\hline \multirow[t]{3}{*}{ TOTAL } & Pearson Correlation & $.616^{\star *}$ & $.616^{\star \star}$ & $.445^{\star}$ & $.594^{\star *}$ & $.456^{*}$ & $.669^{\star \star}$ & 1 \\
\hline & Sig. (2-tailed) & .000 & .000 & .014 & .001 & .011 & .000 & \\
\hline & $\mathrm{N}$ & 30 & 30 & 30 & 30 & 30 & 30 & 30 \\
\hline
\end{tabular}


b. Kualitas Pelayanan

Correlations

\begin{tabular}{|c|c|c|c|c|c|c|c|c|c|c|c|}
\hline & & $\mathrm{KL} 1$ & KL2 & KL3 & KL4 & KL5 & KL6 & $\mathrm{KL7}$ & KL8 & KL9 & TOTAL \\
\hline \multirow[t]{3}{*}{ KL1 } & $\begin{array}{l}\text { Pearson } \\
\text { Correlation }\end{array}$ & 1 & $.502^{* *}$ & $.715^{* *}$ & .190 & $.584^{* *}$ & .292 & .252 & .113 & .000 & $.701^{\star}$ \\
\hline & Sig. (2-tailed) & & .005 & .000 & .315 & .001 & .117 & .179 & .554 & 1.000 & .000 \\
\hline & $\mathrm{N}$ & 30 & 30 & 30 & 30 & 30 & 30 & 30 & 30 & 30 & 30 \\
\hline \multirow[t]{3}{*}{ KL2 } & $\begin{array}{l}\text { Pearson } \\
\text { Correlation }\end{array}$ & $.502^{\star *}$ & 1 & $.510^{* *}$ & .347 & $.404^{*}$ & $.404^{*}$ & -.011 & .065 & .181 & $.717^{\star}$ \\
\hline & Sig. (2-tailed) & .005 & & .004 & .060 & .027 & .027 & .953 & .732 & .339 & .000 \\
\hline & $\mathrm{N}$ & 30 & 30 & 30 & 30 & 30 & 30 & 30 & 30 & 30 & 30 \\
\hline \multirow[t]{3}{*}{ KL3 } & $\begin{array}{l}\text { Pearson } \\
\text { Correlation }\end{array}$ & $.715^{\star *}$ & $.510^{\star \star}$ & 1 & .145 & $.501^{\star \star}$ & $.501^{* *}$ & .048 & -.064 & -.193 & $.600^{*}$ \\
\hline & Sig. (2-tailed) & .000 & .004 & & .445 & .005 & .005 & .801 & .735 & .306 & .000 \\
\hline & $\mathrm{N}$ & 30 & 30 & 30 & 30 & 30 & 30 & 30 & 30 & 30 & 30 \\
\hline \multirow[t]{3}{*}{ KL4 } & $\begin{array}{l}\text { Pearson } \\
\text { Correlation }\end{array}$ & .190 & .347 & .145 & 1 & .281 & .281 & .236 & -.046 & -.026 & $.509^{*}$ \\
\hline & Sig. (2-tailed) & .315 & .060 & .445 & & .133 & .133 & .209 & .811 & .893 & .004 \\
\hline & $\mathrm{N}$ & 30 & 30 & 30 & 30 & 30 & 30 & 30 & 30 & 30 & 30 \\
\hline \multirow[t]{3}{*}{ KL5 } & $\begin{array}{l}\text { Pearson } \\
\text { Correlation }\end{array}$ & $.584^{\star *}$ & $.404^{\star}$ & $.501^{* *}$ & .281 & 1 & $.659^{* *}$ & .167 & .018 & -.079 & $.650^{*}$ \\
\hline & Sig. (2-tailed) & .001 & .027 & .005 & .133 & & .000 & .378 & .927 & .679 & .000 \\
\hline & $\mathrm{N}$ & 30 & 30 & 30 & 30 & 30 & 30 & 30 & 30 & 30 & 30 \\
\hline \multirow[t]{3}{*}{ KL6 } & $\begin{array}{l}\text { Pearson } \\
\text { Correlation }\end{array}$ & .292 & $.404^{*}$ & $.501^{\star *}$ & .281 & $.659^{* *}$ & 1 & .167 & -.114 & -.079 & $.571^{\star}$ \\
\hline & Sig. (2-tailed) & .117 & .027 & .005 & .133 & .000 & & .378 & .549 & .679 & .001 \\
\hline & $\mathrm{N}$ & 30 & 30 & 30 & 30 & 30 & 30 & 30 & 30 & 30 & 30 \\
\hline \multirow[t]{3}{*}{ KL7 } & $\begin{array}{l}\text { Pearson } \\
\text { Correlation }\end{array}$ & .252 & -.011 & .048 & .236 & .167 & .167 & 1 & $.439^{*}$ & .273 & $.488^{\star}$ \\
\hline & Sig. (2-tailed) & .179 & .953 & .801 & .209 & .378 & .378 & & .015 & .145 & .006 \\
\hline & $\mathrm{N}$ & 30 & 30 & 30 & 30 & 30 & 30 & 30 & 30 & 30 & 30 \\
\hline \multirow[t]{3}{*}{ KL8 } & $\begin{array}{l}\text { Pearson } \\
\text { Correlation }\end{array}$ & .113 & .065 & -.064 & -.046 & .018 & -.114 & $.439^{*}$ & 1 & $.608^{* *}$ & .416 \\
\hline & Sig. (2-tailed) & .554 & .732 & .735 & .811 & .927 & .549 & .015 & & .000 & .022 \\
\hline & $\mathrm{N}$ & 30 & 30 & 30 & 30 & 30 & 30 & 30 & 30 & 30 & 30 \\
\hline
\end{tabular}




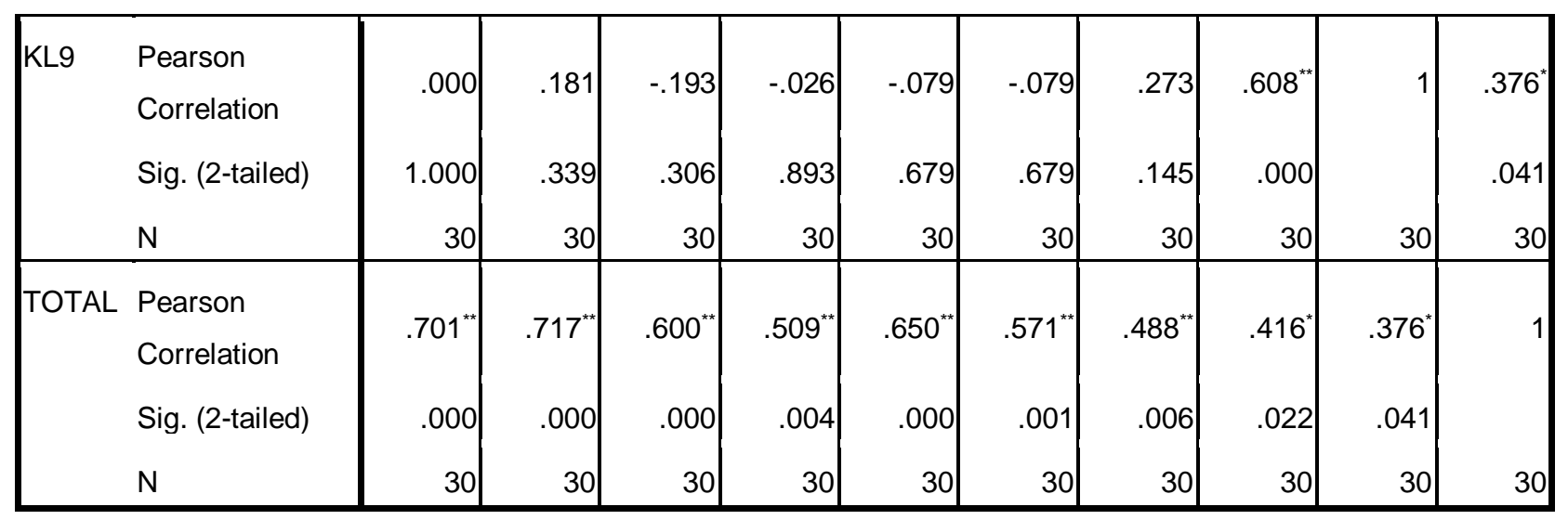

c. Keputusan Pembelian

Correlations

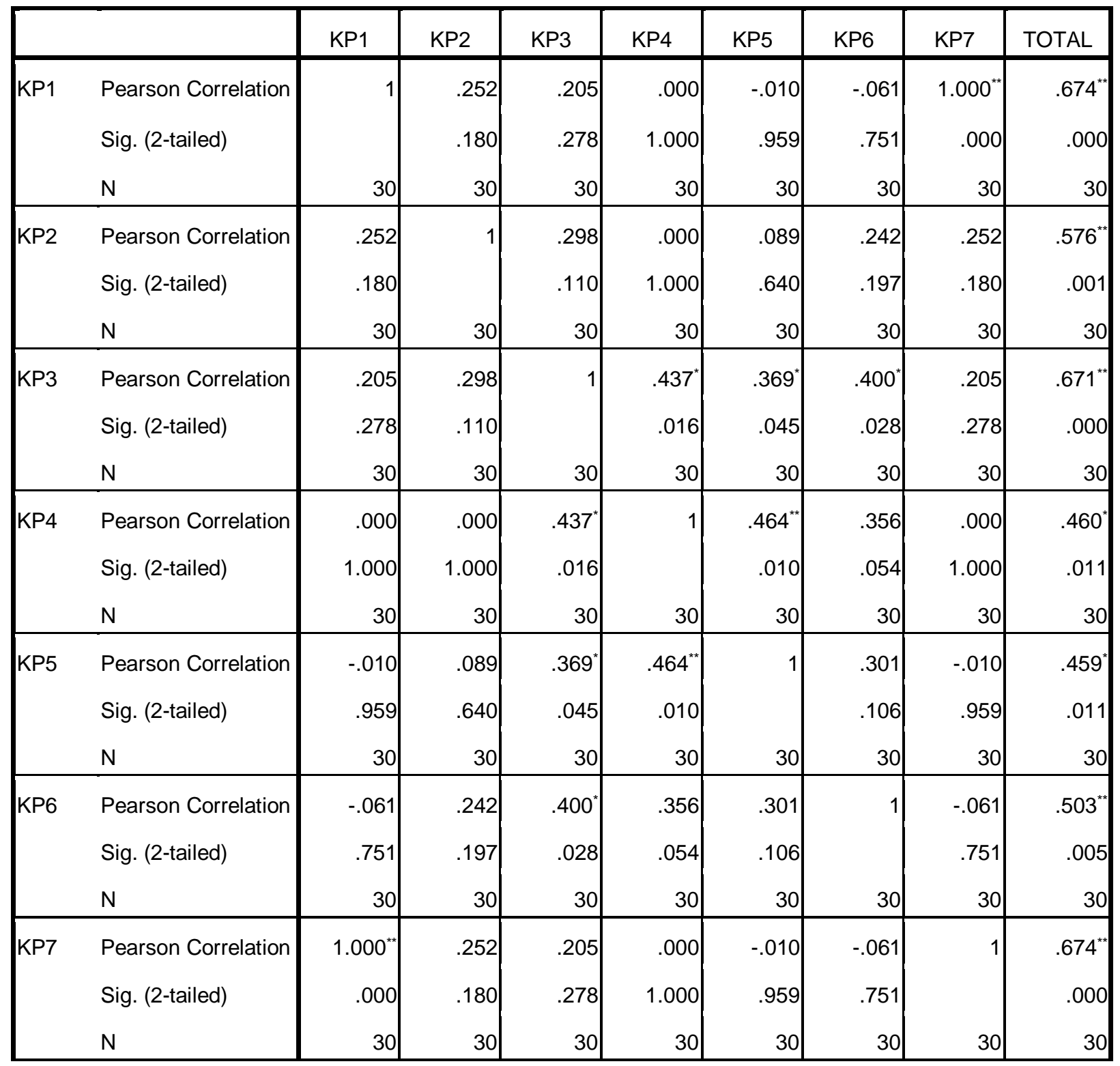




\begin{tabular}{|l|r|r|r|r|r|r|r|r|}
\hline TOTAL Pearson Correlation & $.674^{* *}$ & $.576^{*}$ & $.671^{*}$ & $.460^{*}$ & $.459^{*}$ & $.503^{* *}$ & $.674^{* *}$ & 1 \\
Sig. (2-tailed) & .000 & .001 & .000 & .011 & .011 & .005 & .000 & \\
$\mathrm{~N}$ & 30 & 30 & 30 & 30 & 30 & 30 & 30 & 30 \\
\hline
\end{tabular}

2. Uji Reliabilitas

a. Customer Relationship Management

\begin{tabular}{|r|c|}
\hline \multicolumn{2}{|c|}{ Reliability Statistics } \\
\hline Cronbach's Alpha & N of Items \\
\hline .725 & \\
\hline
\end{tabular}

b. Kualitas Pelayanan

Reliability Statistics

\begin{tabular}{|r|r|}
\hline Cronbach's Alpha & N of Items \\
\hline .731 & 10 \\
\hline
\end{tabular}

c. Keputusan Pembelian

Reliability Statistics

\begin{tabular}{|r|r|}
\hline Cronbach's Alpha & N of Items \\
\hline .733 & 8 \\
\hline
\end{tabular}

